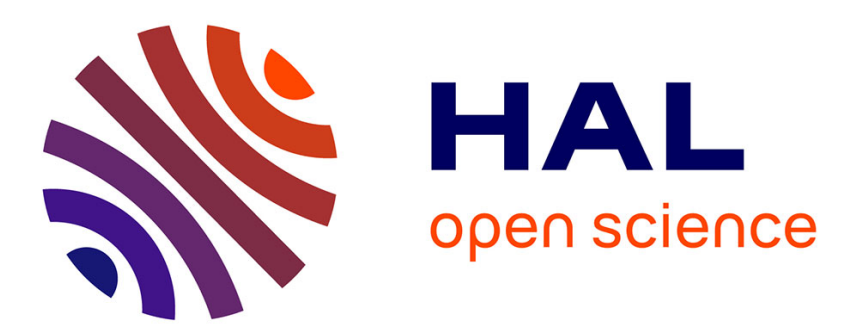

\title{
Mineralogical and geochemical signatures of Quaternary pyroclasts alterations at the volcanic Trindade Island, South Atlantic
}

\author{
A.C.C. Mateus, A.F.D.C. Varajão, Sabine Petit, F.S. Oliveira, C.E.G.R
} Schaefer

\section{To cite this version:}

A.C.C. Mateus, A.F.D.C. Varajão, Sabine Petit, F.S. Oliveira, C.E.G.R Schaefer. Mineralogical and geochemical signatures of Quaternary pyroclasts alterations at the volcanic Trindade Island, South Atlantic. Journal of South American Earth Sciences, 2020, 102, pp.102674. 10.1016/j.jsames.2020.102674 . hal-03001003

\section{HAL Id: hal-03001003 https://hal.science/hal-03001003}

Submitted on 30 Nov 2020

HAL is a multi-disciplinary open access archive for the deposit and dissemination of scientific research documents, whether they are published or not. The documents may come from teaching and research institutions in France or abroad, or from public or private research centers.
L'archive ouverte pluridisciplinaire HAL, est destinée au dépôt et à la diffusion de documents scientifiques de niveau recherche, publiés ou non, émanant des établissements d'enseignement et de recherche français ou étrangers, des laboratoires publics ou privés. 
1 Mineralogical and geochemical signatures of Quaternary pyroclasts 2 alterations at the volcanic Trindade Island, South Atlantic

\author{
A.C.C. Mateus ${ }^{\mathrm{a}}$, A.F.D.C. Varajão ${ }^{a}$, S. Petit ${ }^{\mathrm{b}}$, F.S. Oliveira ${ }^{\mathrm{c}}$, C.E. Schaefer ${ }^{\mathrm{d}}$ \\ ${ }^{a}$ Geology Department, Universidade Federal de Ouro Preto, Campus Morro do \\ Cruzeiro, s/n, Ouro Preto, MG 35-4000-00, Brazil, anacamposeg@ hotmail.com, \\ angelica@degeo.ufop.br \\ ${ }^{\mathrm{b}}$ Institut de Chimie des Mileux et Materiaux de Poitiers (IC2MP), UMR7285CNRS, \\ Université de Poitiers, Poitiers, France, sabine.petit@univ-poitiers.fr \\ ${ }^{\mathrm{c}}$ Geoscinces Institute, Geography Department, Universidade Federal de Minas Gerais, \\ Av. Antônio Carlos, 6627, Belo Horizonte, MG 31-270-901, Brazil, \\ fabiosolos@gmail.com \\ ${ }^{\mathrm{d}}$ Soil Science Department, Universidade Federal de Viçosa, Avenida Peter Henry Rolfs, \\ s/n, Viçosa, MG 36570-000, Brazil, carlos.schaefer@ufv.br \\ *Corresponding author: Ana Carolina Campos Mateus, anacamposeg@hotmail.com, \\ Tel: +55 $353212-5310$
}

\begin{abstract}
This paper reports the composition and alteration products of pyroclasts in the Holocene Paredão volcano (pyroclast 1) and Late Quaternary Morro Vermelho Formation (pyroclasts 2 and 3) of Trindade Island, South Atlantic, Brazil using combined macromorphological, micromorphological, mineralogical and geochemical techniques. The pyroclasts 1 and 2 are interpreted as volcanic tuff breccia deposits, whereas pyroclast 3 is a lapilli deposit. They are dark gray in color with some altered reddish regions and show vesicles and amygdales structures with small greenish crystals of 2.0 $\mathrm{mm}$ scattered throughout the matrix. The eruptions can be regarded as Strombolian-type by producing pyroclastic deposits with coarse fragments with high vesicularity and fluidal shape that indicate magmatic degassing and fragmentation. Petrologic and XRD data revealed a mixture of biotite, goethite, ilmenite, anatase, magnetite, hematite, pyroxene, zeolites, and olivine as their main mineral components. Optical microscopy analysis confirms the vesicular and amygdaloid structures, with a hypocrystalline texture and a pale brown stained vitreous mass classified as sideromelane, due to its basaltic composition. The sideromelane changes to a reddish brown and yellowishbrown staining material identified as palagonite, clearly indicating a hydrovolcanic eruption that occurs when the ascending magma comes into contact with water. Infrared analyses in the palagonitized regions revealed the presence of halloysite, suggesting alteration of sideromelane to tubular clay minerals. Amygdales and microfractures are partially or totally filled with zeolites, which are formed by the percolation of water that reacts with the palagonite and precipitation of chemical elements of hydrothermal fluid. Reddish dark brown iddingsite and anhedral crystals of titaniferous magnetites occur in the fractures and edges of the olivine. These crystals are also dispersed in the matrix while some of them are zoned with Cr-rich core and Cr-poor edge, suggesting a deep mantle origin of the magma. The high trace elements content can be related to clinopyroxene (diopside) that include these elements. Geochemical data show that the pyroclasts are undersaturated in silica, plotting in the ultrabasic and foidites fields on the TAS classification diagram.
\end{abstract}

Keywords: Palagonite; Halloysite; Zeolites; Infrared 


\section{Introduction}

The Trindade Island is a small Brazilian island of $\sim 13 \mathrm{~km}^{2}$ and located in the South Atlantic (Fig. 1). The Island is part of an extensive east-west-oriented underwater volcanic chain, called Vitória-Trindade, and constitutes the upper portion of a volcanic building of $\sim 5.2 \mathrm{~km}$ high. The Vitória-Trindade Chain corresponds to the western extension of the Trindade Victory Fracture Zone, located at $18^{\circ} 40^{\prime}$ in the Mid Atlantic Ridge (Alves et al., 2006). The Island is formed by five different volcanic episodes of lava flows and intrusions of poor silica rocks with accentuated sodium-alkaline content (Almeida, 1961). These volcanic episodes were described by Almeida (1961) from bottom to top as: Trindade complex, Desejado sequence, Morro Vermelho Formation (MV), Valado Formation and Vulcão do Paredão Formation (VP) (Fig.1). The volcanic spills are overlain by the Holocene deposits that represent a small portion of the stratigraphic units occurring on the island (Castro and Antonello, 2006) (Fig.1). Particularly in MV and VP formations, there are several pyroclasts such as lapilli and ash tuffs containing rotational lumps, blocks, aggregates and agglutinates of melanefelintic, basanite and tephrytic lava. Cordani (1970) suggested an eruption age by potassium-argon dating method of 0.17 Ma for the MV deposits. However, Pires et al. (2016) a recorded a $0.25 \mathrm{Ma}$ age for the VP volcanic deposits and suggests that this volcanism represents the most recent volcanic activity of the Brazilian territory.

Studies of volcano stratigraphy and eruption geological models in the area of the Paredão Volcano (Pasqualon, 2017) and Morro Vermelho Formation (Luz, 2016) showed intercalation of nephelinitic flows and pyroclastic deposits, leading to the interpretation of heterogeneous volcanism characterized by an early stage of the Hawaiian style eruption (Sumner et al., 2005; Parcheta et al., 2012; Rader et al., 2015), and a final phase of the Strombolian style. According to Pasqualon (2017) and Luz (2016), the Hawaiian style is represented, in the study area, exclusively by a'a flows but without describing the a'a morphotypes (Murcia et al., 2014). The Strombolian style is represented by pyroclasts deposits of tuff breccia and lapilli being composed mainly of basaltic scoria (Pasqualon, 2017 and Luz, 2016).

The petrological and geochemical studies of the olivine-nephelinites in the VP rocks showed strongly fractionated REE patterns in the melanephelinites and basanitestephrites, suggesting the presence of garnet as a probable residual phase and generation of melt at about $100 \mathrm{~km}$ depth (Marques et al., 1999). Bongiollo et al. (2015) recently 
used geochemical modeling to show that the nephelinites in Trindade Island were from magmas derived at a minimum of $1490{ }^{\circ} \mathrm{C}$ and $3 \mathrm{Gpa}(>100 \mathrm{~km}$ depth).

Studies to date have focused on the petrogenesis and age of lava flows and intrusions on Trindade Island.

Except for studies of alteration of olivine crystals of the pyroclasts (Mateus et al., 2018), there is still a deficiency of studies with emphasis on alteration of the rocks, that evolve specific factors like young volcanic parent materials, interaction with seawater and climate conditions. Detailed studies analyzing the features of palagonization and zeolitization, which are constantly found on oceanic islands with basic rocks consisting of sideromelane altered to palagonite (Wentworth, 1926; Stearns and Vaksvik, 1935; Nakamura, 1961; Einarsson, 1965; Thorseth et al., 1991) and to zeolite (Nayudu, 1964; Hay and Iijima, 1968; Iijima and Harada, 1969; Kristmannsdóttir and Tómasson, 1978), can be used to understand the mechanisms involved in the transformations of pyroclatic rocks from the Trindade Island.

Therefore, this study used combined macromorphological, micromorphological, mineralogical and geochemical techniques to examine the composition, alteration products, and origin of the pyroclasts in MV and VP formations.

\section{Methodology}

The pyroclastic rocks were collected from the Holocene VP Formation (the latest event) and the Late Quaternary MV formation. Macromorphologically, the coloration and the mineral constituents of the rocks were observed with the aid of a magnifying glass of $20 x$. The pyroclasts were measured and classified according to the systematic of the IUGS (Le Maître, 2002) taking into account the size of the clasts. The petrological description including mineralogy, texture, estimation of the percentage of minerals and photographic images were performed in polished thin sections using a Zeiss microscope coupled with a camera.

More detailed mineralogical information was obtained on the samples using X-Ray Diffraction (XRD) technique. The samples were initially gently powdered in agate mortar and sieved with 250 mesh. The samples were analyzed at a scanning interval of 2 to $70^{\circ} 2 \theta$ with a step size of $0.02^{\circ} 2 \theta / \mathrm{s}$ using a $\mathrm{CuK} \alpha$ radiation and power $45 \mathrm{KV}$ and $40 \mathrm{~mA}$ on a Panalytical diffractometer at the Universidade Federal de Ouro Preto (DEGEO/UFOP), Brazil. The diffractograms were interpreted with X'pert HighScore 
Plus software and compare with standards (Brindley and Brown, 1980). The Transform Fourier Thermo Nicolet, Nexus 5700 series infrared spectrometer coupled with Thermo Scientific Nicolet Continum microscope was used to complement the XRD mineralogical analyses at the IC2MP institute, Université de Poitiers, France. These analyses were performed on clay fractions and point analyses in thin sections. In microscope the near-infrared spectra $\left(8000-4000 \mathrm{~cm}^{-1}\right)$ were obtained using source of white light, beamsplitter $\mathrm{CaF}_{2}$, resolution of $4 \mathrm{~cm}^{-1}$, optical velocity of $0.3165 \mathrm{~cm} \mathrm{~s}^{-1}$ and 100 scans. The spectra of clay fraction were obtained with the same condition of acquisition in thin sections, but with velocity of $0.12659 \mathrm{~cm} \mathrm{~s}^{-1}$.

Image analyses of the clay minerals were performed with a JEOL 2011 Bruker Esprit Transmission Electron Microscope (TEM) at CinaM-CNRS, Aix Marseille University. The suspended clay separates were deposited onto carbon coated Formvar film $\mathrm{Cu}$ grids. The palagonitized regions were scraped and then deposited in resin to be made cuts in ultramicrotome. The cuts were deposited in grids.

The chemical analyses of the major and trace element compositions of the samples were measured in the ICP-OES Agilent Technologies 725 while the rare earth elements (REE) were performed in the ICP-MS Agilent Technologies 7700 at DEGEO/UFOP LGqa Laboratory. For total digestion of $0.1 \mathrm{~g}$ of each sample, $1 \mathrm{ml}$ of hydrogen peroxide, $3 \mathrm{ml}$ of $\mathrm{HCl}$ at $10 \mathrm{~mol} / \mathrm{L}, 6 \mathrm{ml}$ of $\mathrm{HNO}_{3}$ to $10 \mathrm{~mol} / \mathrm{L}, 20 \mathrm{ml}$ of $\mathrm{HNO}_{3}$ to $2 \mathrm{~mol} / \mathrm{L}$ and $4 \mathrm{ml}$ of $\mathrm{HF}$ concentrate were used. The percentage of $\mathrm{SiO}_{2}$ was calculated in a relative way by the difference to $100 \%$ in the sum of the main elements and LOI.

Back-scattered electron images and semi-quantitative chemical analyses by Electron Dispersive X-ray (EDX) were made to analyze the habit and chemical compositions, respectively, of the volcanic glass and palagonite. These analyzes were made in Scanning Electron Microscope (SEM) coupled with EDX Jeol JSM-6510 with an operating voltage of $20 \mathrm{KV}$.

The microanalyses of the olivines, pyroxenes, zeolites, spinels, sideromelane and palagonite were performed with electron microprobe JEOL JXA-8230 at the Microanalysis Laboratory of the DEGEO/UFOP. The acceleration and current conditions were $15 \mathrm{kV}$ and $20 \mathrm{nA}$, and corrections of the common ZAF matrix were applied. The counting time in the peaks/background were $10 / 5$ s for all elements except the sodium that was 20/10s ( $\mathrm{Na}, \mathrm{Si}, \mathrm{Al}, \mathrm{Mg}, \mathrm{Fe}, \mathrm{Cr}, \mathrm{Ti}, \mathrm{Ca}, \mathrm{Ni}, \mathrm{K}, \mathrm{Mn}$ ). The punctual analyses were calibrated with jadeite-TAP, rutile-LIF, sanidine-PETJ, magnesium-TAP 
oxide, chromium-LIF oxide, AN100-PETJ, corindon-TAP, rodonite-LIF, quartz-TAP, magnetite-LIF. The $\mathrm{FeO}$ was considered as the amount of total iron obtained through the microprobe.

\section{Results}

The pyroclastic rocks collected in the VP (pyroclast 1) and MV formations (pyroclasts 2 and 3) were classified according to their sizes (Le Maitre, 2002). The pyroclasts 1 and 2 are classified as tuff breccia deposit according to diagram of Németh and Martin (2007). The pyroclasts 1 and 2 contain more than 75\% of angular and subangular fragments larger than $64.0 \mathrm{~mm}$ (blocks) (Figs. 2A, C). In addition, pyroclast 1 contains fragments between 2.0 and 64.0mm (lapilli; Fisher, 1966) in smaller proportions (Fig. 2B). The pyroclast 3 belongs to a lapilli deposit containing more than $75 \%$ of 2.00 to $64.00 \mathrm{~mm}$ (lapilli) fragments (Figs. 2D, E). Macroscopically, all the pyroclasts have dark gray color with some brownish to reddish regions, and vesicular and amygdaloid structures (Fig. 2). The matrix of the pyroclasts contain scattered small green crystals $(\sim 2.0 \mathrm{~mm})$. Owing to the fine-grained size $(<1.0 \mathrm{~mm})$ of the matrix constituents, it is difficult to distinguish their mineral composition in macroscopic view.

Microscopically the pyroclast 1 are altered and show reddish brown vitreous matrix (Fig. 3A) that is attributed to exposure to intense alteration. Some regions of pyroclasts 2 have grayish stains because of the presence of unaltered portions of the rock (Fig. 3E). However, fragments in pyroclast 3 are yellowish brown in color (Fig. 3J). All the pyroclasts have vesicular and amygdaloid structures and hypocrystalline textures (Figs. $3 \mathrm{~A}, \mathrm{D}, \mathrm{J})$. The pyroclasts are composed of a pale brown vitreous mass in $50 \%$ of thin section area, which are isotropic in crossed polarized light and occurs around olivine, pyroxene and spinel crystals. Bulk rock XRD analyses show that the matrix of these pyroclasts are essentially composed of biotite, goethite, ilmenite, anatase, magnetite, hematite, pyroxene and olivine (Mateus et al., 2018).

Glass - The vitreous mass (glass) is classified as sideromelane due to the basaltic composition of the pyroclasts (Table 1; Figs. 4B, C). The sideromelane changes to a reddish brown (Fig. 3B) and yellowish brown (Fig. 3K) materials identified as palagonites. In pyroclast 1 , the glass is totally palagonitized and it is possible to find only sideromelane in pyroclasts 2 and 3 . The reddish colorations are due to a high degree of alteration and high Fe content. In some portions, palagonite is whitish (Fig. $3 \mathrm{~K}$ ) due to leaching of $\mathrm{Fe}$ in the reddish brown and yellowish brown palagonite. This 
process is similar to what was observed in palagonites of Iceland (Thorseth et al., 1991). Chemical analyses of the palagonite showed a loss of alkali and alkaline-earth elements $(\mathrm{Na}, \mathrm{Ca}, \mathrm{Mg}$ ) and enrichment of $\mathrm{Fe}$ and water in relation to the sideromelane (Table 1) in the reddish and yellowed regions. This composition is similar to those found in palagonites from previous studies such as Peacock (1926, 1928), Thorseth et al. (1991), Stroncik and Schmincke $(2001,2002)$ and Pauly et al. (2011). The infrared analyses in the palagonitized regions of pyroclasts 1 and 2 showed the presence of halloysite (Fig. 5). Notably, the characteristic bands of halloysite are observed at about 7070, 7200, and $4530 \mathrm{~cm}^{-1}$. The two former bands are attributed to the first overtones of the $\mathrm{Al}_{2} \mathrm{OH}$ stretching vibrations and the latter band to the $\mathrm{Al}_{2} \mathrm{OH}$ stretching plus bending combination mode (Madejová et al., 2011). Images of TEM confirm the presence of tubular halloysite in the clay fraction of the altered and palagonitized portions of the pyroclasts. The diameter of the tubes ranges from 0.1 to $0.2 \mu \mathrm{m}$ (Fig. 6). Figure 6B shows a halloysite crystal and a fragment of volcanic glass.

Olivine - Olivine is euhedral, forsterite $\left(\mathrm{Fo}_{80}\right)$ in composition (Mateus et al., 2018) and makes up $20 \%$ of the rock in all the pyroclasts. The olivine phenocrysts in pyroclast 1 are essentially altered and fractured with axis sizes greater than $1 \mathrm{~mm}$ (Fig. 3A). The fractures and edges of these altered and fractured olivine phenocrysts in pyroclasts 1 are filled and corroded with reddish dark brown colored iddingsite (Fig. 3A). However, well preserved olivine phenocrysts with sizes ranging from $0.5 \mathrm{~mm}$ to $3 \mathrm{~mm}$ dominate pyroclasts 2 and 3 (Figs. 3D, L).

Pyroxene - The pyroxenes were observed as very small crystals about of $70 \mu \mathrm{m}$ in the form of microliths in the vitreous matrix and present in trace amount $(5 \%)$ in pyroclast 1 (Fig. 3B). Pyroxenes in pyroclast 2 are mostly tiny $(20 \mu \mathrm{m})$, dispersed in the matrix and surround the olivine phenocrysts with high interference colors, and are present in small amount (15\%). However, largest crystals of $\square 120 \mathrm{~mm}$ are rarely found (Fig. 3F). In the pyroclast 3 , prismatic pyroxenes, constituting about $25 \%$, are tiny ( $\square 20 \mu \mathrm{m}$ ) and occur within the microlytic matrix and surrounding the olivine phenocrysts (Fig. 3L). Electron microprobe micro-chemical analyses show that the pyroxene in pyroclasts 1 and 2 are diopside (Table 2; Fig. 7). TEM analyses also show occurrence of fragments of pyroxene in clay fraction (Fig. 6D). Spinels - Spinels are commonly observed dispersed in the matrix of the pyroclasts, and within the fractures and edges of olivine phenocrysts in varying trace amounts $(5-10$ 
$\%$; Fig. 3C). The crystals are anhedral and are about $0.05 \mathrm{~mm}$ in size. Electron microprobe analyses shows that the spinels are titaniferous magnetites, and some crystals display Cr-rich and Cr-poor zones (Table 3; Figs. 4E, G, H). Due to the degree of alteration of the spinels, it was difficult and nearly impossible to determine their chemical composition as none of the analysis was close to $100 \%$. Zeolite - In pyroclast 2, amygdales and microfractures are partially to completely fill by zeolites (Figs. 3D, E, H). The zeolites are small pseudorhombohedral crystals (Fig. 3E), mostly less than $20 \mu \mathrm{m}$, with low interference colors, and constitute about $10 \%$ in thin section observations. The zeolites filled microfractures sometimes crosscut the olivine crystals (Figs. 3G, I) and vesicles (Fig. 3I), suggesting their latter and secondary crystallization. The zeolites also crystallize in the walls of the palagonitized portions (Fig. 4F).

Electron microprobe analyses of the zeolites in pyroclast 2 shows that they are predominantly heulandite-Ca and chabazite-Ca (Table 4; Figs. 4F, G). Both the heulandite-Ca and chabazite-Ca are found in the amygdales filled zeolites while those in the microstructure veins are essentially chabazite-Ca. The average calculated structural formula is $\left(\mathrm{Ca}_{3.17} \mathrm{Na}_{0.85} \mathrm{~K}_{4.28}\right)_{8.3}\left(\mathrm{Si}_{21.58} \mathrm{Al}_{10.34}\right) \mathrm{O}_{72 .} .26 \mathrm{H}_{2} \mathrm{O}$ and $\mathrm{Ca}_{1.31}\left(\mathrm{~A}_{14.42} \mathrm{Si}_{7.6} \mathrm{O}_{24}\right) \cdot 13 \mathrm{H}_{2} \mathrm{O}$ for the heulandite-Ca and chabazite-Ca, respectively. The $\mathrm{Si}$ Al ratios are relatively low in the heulandite- $\mathrm{Ca}(2.08)$ and chabazite-Ca (1.74).

Geochemical of pyroclasts - The pyroclasts are undersaturated with silica ( $37 \%)$. $\mathrm{Na}_{2} \mathrm{O}$ content is higher than $\mathrm{K}_{2} \mathrm{O}$ in pyroclasts 1 and 2 but lower in pyroclast 3 (Table 5). All the pyroclasts plot in the ultrabasic rocks and foidites fields on the $\mathrm{Na}_{2} \mathrm{O}+\mathrm{K}_{2} \mathrm{O}$ vs $\mathrm{SiO}_{2}$ TAS classification diagram (Fig. 8; Les Bas et al., 1986). The high FeOt, MgO, $\mathrm{TiO}_{2}$ and $\mathrm{CaO}$ contents in all the pyroclasts (Table 5) are probably due to the presence of ferromagnesian minerals such as magnetites, olivines, ilmenites and clinopyroxene. The pyroclasts are also enriched in trace elements, such $\mathrm{Ba}, \mathrm{Cr}, \mathrm{Sr}, \mathrm{V}, \mathrm{Zr}, \mathrm{Zn}$ and $\mathrm{Ce}$ (Table 5). The elevated trace elements contents are related to the presence of pyroxenes as shown by Panina and Stoppa (2009) who documented the enrichments of trace elements in clinopyroxenes in foidian olivine in southern Italy. Moreover, the pyroclasts display strong enrichments of light rare earth elements (LREE) over the heavy rare earth elements (HREE) ( $\sum$ LREE $/ \sum$ HREE $=12.38$ to $13.71 ; \mathrm{La} / \mathrm{Yb}=33.55$ to 40.85 , Table 5.5 and Fig. 9).

\section{Discussions}




\subsection{The eruption type and the alteration process of pyroclasts}

According to Walker and Croasdale (1971), the eruptions during the formation of pyroclastic deposits can be regarded as Strombolian-type by producing initially coarse materials, with a restricted range of sizes. This affirmation is attested in this study by the presence of blocks and lapilli. Additionally, the high vesicularity and fluidal shape presented by the fragments, that indicate degassing and magmatic fragmentation, are characteristic of Strombolian-type eruption (Vergniolle and Brandeis, 1996; Vergniolle et al., 1996; Houghton et al., 1999). The Strombolian-type eruption is supported by studies of Pasqualon (2017) and Luz (2016) on pyroclasts deposits in the areas of this study.

The main alteration products of pyroclasts are: palagonite, iddingsites, halloysite and zeolites.

The palagonite is an alteration product of volcanic glass (like sideromelane) and its presence is characterized by regions with reddish and yellowish color due to the relative concentration of iron due to the loss of more mobile chemical elements such as $\mathrm{Na}, \mathrm{K}$, $\mathrm{Mg}$ (Stroncik and Schimincke, 2002). Several authors consider that the palagonite is the first stable product of aquatic mafic glass alteration (Peacock, 1926; Hay and Iijima, 1968; Staudigel and Hart, 1983; Furnes, 1984; Thorseth et al., 1991). Bunsen (1847) and Correns (1930) were the first to observe that the alteration of sideromelane to palagonite results in loss of some elements. An explanation for the formation of palagonite would be a hydrovolcanic eruption that occurred when the ascending magma came into contact with sea water at high tide (Stroncik and Schimincke, 2001). The process of palagonitization by the hydrovolcanic eruption (Németh and Kósik, 2020) has been previously described in volcanic islands, such as the Azores, Hawaii (Wentworth, 1926; Stearns and Vaksvik, 1935) and Oshima (Nakamura, 1961); and in lakes or low ground with a high groundwater in Auckland (Searle, 1965), Idaho (Hamilton and Bvers, 1963) and Iceland (Einarsson, 1965). According to Bonati (1965), hydration of the lava is probably faster at higher temperatures when the lava is still in a molten state. During this phase, the hydrous lava forms directly hydrated glass (palagonite). This process seems to have occurred in the pyroclast 2 because there is a large amount of yellowish brown palagonite with little sideromelane.

Following the complete consolidation of magma and the alteration of volcanic glass as a result of seawater interaction, the pyroclasts underwent a second phase of alteration due 
to exposure to meteoric water. The presence of halloysite in the palagonitized sideromelane attested by infrared and MET analyses; the crystals of olivine and amigdals cut by zeolites veins, the presence of zeolites crystallized in palagonitized regions; and the presence of iddingsitized olivines (see Mateus et al., 2018) corroborate this proposition.

Alterations of sideromelane to zeolites have been described in palagonite tuffs from Oahu, Hawaii (Hay and Iijima, 1968; Iijima and Harada, 1969) and Iceland (Nayudu, 1964). The probable formation of zeolites in pyroclast 2 would to be the reaction of sideromelane with meteoric fluid in temperature around of $100^{\circ} \mathrm{C}$. According to Kristmannsdóttir and Tómasson (1978), heulandite, stilbite and analcime may form at temperatures below $100^{\circ} \mathrm{C}$. Barrows (1980) described heulandite, clinoptilolite, mordenite, analcime, thomsonite, erionite and chabazite in thick Miocene volcaniclastic sequences in Nevada attributed to a process involving the circulation of low temperature meteoric fluid in an open hydrologic system. Höller and Wirsching (1980) observed the formation of chabazite, phillipsite, and analcime in the reaction of nephelinite with a solution of $0.01 \mathrm{~N} \mathrm{NaOH}$ at $150^{\circ} \mathrm{C}$ in open system.

In this study, the meteoric water reacted with the vitreous matrix of the rock to form the palagonite and precipitated the $\mathrm{Si}, \mathrm{Al}, \mathrm{Ca}, \mathrm{Na}$, and $\mathrm{K}$ in the form of zeolites in the adjacencies of the palagonite, similar to the one described by Hay and Iijima (1968) and Iijima and Harada (1969) in zeolithic palagonite tuffs. The occurrence of zeolites impoverished in silica is due to the low silica contents in the pyroclasts and primary basaltic magma.

In all pyroclasts occur olivines iddingsitized by meteoric water. The difference in the degree of preservation or alteration of olivine phenocrysts between VP (pyroclast 1) and MV (pyroclasts 2 and 3) is related to their position on the sampling profile (Mateus et al., 2018). The pyroclast 1 was collected at higher altitude and in a more humid region, exposing it to greater leaching and alteration processes compared to pyroclasts 2 and 3 that were collected from much lower altitude with less exposure to alterations. Mateus et al. (2018) argue that the presence of iddingsite in the high altitude and humid region indicates an advanced alteration stage of the olivine crystals during weathering.

\subsection{Geochemical considerations}


The presence of spinels enriched with chromium and the LREE enrichment indicate that the magma has a mantelic origin (Irvine, 1965).

The strongly fractionated REE patterns suggest the presence of garnet as a probable residual phase, implying that melt generation occurred at depths of about $100 \mathrm{~km}$. This interpretation is corroborated by the earlier work of Marques et al. (1999), who suggested a garnet magma source at deeper depth $(\sim 100 \mathrm{~km})$ for the olivine-nephelinites in the VP Formation and proven by Bongiollo et al. (2015) through geochemical modeling.

\section{Conclusions}

The Quaternary pyroclastic rocks of the Vulcão do Paredão (Holocene) and Morro Vermelho (Pleistocene) showed the following products of alteration:

1- sideromelane palagonitized through the interaction of magma with the sea water and subsequently with meteoric water;

2- particularly in the pyroclast 2, the palagonite alters to form zeolite and halloysite through the passage of hydrothermal fluids and meteoric water during weathering.

The main factors justifying this assertion are:

1- in the palagonitized regions there is a loss of bases $(\mathrm{Na}, \mathrm{Ca}, \mathrm{Mg})$ and an enrichment of Fe and water in relation to the sideromelane;

2.1- the chemical analysis by microprobe showed the presence of zeolites alongside the palagonite;

2.2- the point-source analyses of infrared allow to identify halloysite in the palagonite of pyroclast with totally altered sideromelane;

2.3- TEM observations confirm the presence of halloysite in the palagonitized regions. In addition, the presence of palagonite may indicate a hydrovolcanic eruption for these deposits.

\section{Acknowledgements}

Special thanks to the Brazilian Navy for their logistical support and to the $\mathrm{CNPq}$ (306424/2016-9; 442730/2015-2), CAPES (scholarship) and FAPEMIG (PPM- 0032618 ) and the European Union (ERDF) and Région Nouvelle Aquitaine for their financial contribution. We would also like to express our gratitude to Olivier Grauby (CINam- 
CNRS - Aix Marseille University) for assistance in the TEM observations, the Microanalysis Laboratory of the Universidade Federal de Ouro Preto, member of the Microscopy and Microanalysis Network of Minas Gerais State/Brazil/FAPEMIG and to the Laboratory of Microanalysis and Electronic Microscopy of the Microscopy Center of the Universidade Federal de Minas Gerais for the mineral chemical analyses. Lastly, we would like to show our appreciation to the Laboratory of X-Ray Diffraction of DEGEO/UFOP DRX and laboratory IC2MP, Université de Poitiers for the mineralogical analyses. The authors would like to thank the reviewers Karoly Nemeth and Sorin C. Barzoi, who greatly improved our manuscript.

\section{References}

Almeida, F.F.M., 1961. Geologia e petrologia da Ilha de Trindade. Serviço Gráfico do Instituto Brasileiro de Geografia e Estatística, Rio de Janeiro, 197 p.

Alves, E.C., Maia M., Sichel S.E., Campos, C.M.P., 2006. Zona de Fratura de Vitória-Trindade no oceano atlântico sudeste e suas implicações tectônicas. Rev. Bras. Geofis. 24(1),117-127.

Barrows, K.J.,1980. Zeolitization of Miocene volcanoclastic rocks, southern Desatoya Mountains, Nevada. Geol. Soc. Am. Bull. 91,199-210.

Bonatti, E., 1965. Palagonite, hyaloclastites and alteration of volcanic glass in the Ocean. Bull. Volcanol. 28(1), 257-269.

Bongiolo, E.M., Pires, G.L.C., Geraldes, M.C., Santos, A.C., Neumann, R., 2015. Geochemical modeling and Nd-Sr data links nephelinite-phonolite successions and xenoliths of Trindade Island (South Atlantic Ocean, Brazil). J. Volcanol. Geotherm. Res. 306, 58-73.

Brindley, G.W., Brown, G., 1980. Crystal Structures of Clay Minerals and Their Xray Identification. Mineralogical Society, London, 495 p.

Bunsen, R.,1847. Beitrag zur Kenntnis des isländischen Tuffgebirges. Ann. Chem. Pharm. 61, 265-279.

Castro, J.W.A., Antonello, L.L., 2006. Geologia das ilhas oceânicas brasileiras. In: Alves, R.J.V., Castro, J.W.A. (Eds.), Ilhas Oceânicas Brasileiras: da Pesquisa ao Manejo. Ministério do Meio Ambiente, Brasília, pp. 29-57. 
Cordani, U. G. 1970. Idade do vulcanismo do Oceano Atlântico Sul. São Paulo: Instituto de Geociências e Astronomia. Boletim IGA, 1, 9-75.

Correns, C. W., 1930. Über einen Basalt vom Boden des atlantischen Ozeans und seine Zersetzungsrinde. Chem. Erde. 5, 76- 86.

Einarsson, T., 1965. The ring-mountains Hverfiall, Lúdent, and Hrossaborg in northern Iceland. Vísindafélag Íslendinga, Greinar 41, 1-28.

Fisher, R.V., 1966. Rocks composed of volcanic fragments. — Earth Science Review 1, pp. 287-298.

Furnes, H., 1984. Chemical-changes during progressive subaerial palagonitization of a subglacial olivine tholeiite hyaloclastite - a microprobe study. Chem. Geol. 43, $271-285$.

Hamilton, W., Bvers, W.B., 1963. Menan Buttes, cones of glassy basalt tuff in the Snake River Plain, Idaho. U. S. Geol. Surv. 450-E, 114-118.

Hay, R.L., Iijima, A., 1968. Petrology of Palagonite Tufts of Koko Craters, Oahu, Hawaii. Contr. Mineral. and Petrol.17, 141-154.

Höller, H., Wirsching, U., 1980. Experiments on the hydrothermal formation of zeolites from nepheline and nephelinite. Proc. 5th Int'1 Conf on Zeolites, Heyden, London, pp. 164-170.

Houghton, B.F., Wilson, C.J.N., Smith, I.E.M., 1999. Shallow-seated controls on styles of explosive basaltic volcanism: a case study from New Zealand. J. Volcan. Geoth. Res. 91 (1), 97-120.

Iijima, A., Harada, K., 1969. Authigenic zeolites in zeolitic palagonite tuffs on Oahu, Hawaii. Am. Mineral. 54, 182-197.

Irvine, T.N., 1965. Chromian spinel as a petrogenetic indicator. Part. 1. Theory. Canad. J. Earth Sci. 2, 648-672.

Kristmannsdóttir, H., Tómasson, J.,1978. Zeolite zones in geothermal areas, Iceland. In: Sand, L.B., Mumpton, F.A. (Eds.), Natural Zeolites. Pergammon Press, Oxford, pp. 277-284. 
Le Bas, M.J., Le Maître, R.W., Streckeisen, A., Zanettin, B., 1986. A chemical classification of volcanic rocks based on the total alkali-silica diagram. J. Petrol. $27,745-750$.

Le Maître, R.W., Batema, N.P., Dudek, A., Keller, J., Lameyre, J., Le Bas, M.J., Sabine P.A., Schmid, R., Sorensen, H., Streckeisen, A., Woolley, A.R., Zanettin, B., 2002. Igneous Rocks: A Classification and Glossary of terms. Cambridge University Press, New York, 236 p.

Luz, F. R., 2016. Estudo do Vulcanismo da Ilha da Trindade: estratigrafia e petrologia da Formação Morro Vermelho. Monography, Porto Alegre, Instituto de Geologia/Universidade Federal do Rio Grande do Sul, 112p.

Madejová, J., Balan, E., Petit, S., 2011. Application of vibrational spectroscopy to the characterization of phyllosilicates and other industrial minerals. In: Christidis, G.E. (Ed.), Advances in the characterization of industrial minerals, EMU Notes in Mineralogy. European Mineralogical Union and Mineralogical Society of Great Britain and Ireland, Cambridge, pp.171-226.

Marques, L.S., Ulbrich, M.N.C., Ruberti, E., Tassinari, C.G., 1999. Petrology, geochemistry and Sr-Nd isotopes of Trindade and Martin Vaz volcanic rocks (Southern Atlantic Ocean). J. Volcan. Geoth. Res. 93, 191-216.

Mateus, A.C.C., Varajão, A.F.D.C., Oliveira, F.S., Schaefer, C.E., 2018. Alteration of olivine in volcanic rocks from Trindade Island, South Atlantic. Appl. Clay Sci. 160, 40-48.

Morimoto, M., 1988. Nomenclature of pyroxenes. Min. Mag. 52, 535-550.

Murcia, H., Németh, K., Moufti, M.R., Lindsay, J.M., El-Masry, N., Cronin, S.J., Qaddah, A., Smith, I.E.M., 2014. Late Holocene lava flow morphotypes of northern Harrat Rahat, Kingdom of Saudi Arabia; implications for the description of continental lava fields. J. Asian Earth Sci. 84, 131-145.

Nakamura, K., 1961. Stratigraphic studies of the pyroclastics of Oshima Volcano deposited during the last fifteen centuries. II. Activity of parasitic volcanoes. Sci. Pap. Coii. Gen. Educ., Univ. Tokyo 11, 281-319.

Nayudi, Y.R., 1964. Palagonite tufts (hyaloclastites) and the products of post-eruptive processes. Bull. Volcanol. 27, 391-410. 
Németh, K., Martin, U., 2007. Practical volcanology - Lecture notes for understanding volcanic rocks from field based studies. Geological Institute of Hungary, Budapest, 221p.

Németh, K., Kósik, S., 2020. Review of Explosive Hydrovolcanism. Geosciences 10(2), 44 .

Panina, L.I., Stoppa, F., 2009. Silicate-carbonate-salt liquid immiscibility and origin of the sodalite-haüyne rocks: study of melt inclusions in olivine foidite from Vulture volcano, S. Italy. Cent. Eur. J. Geosci. 1(4), 377-392.

Parcheta, C.E., Houghton, B.F., Swanson, D.A., 2012. Hawaiian fissure fountains 1: decoding deposits-episode 1 of the 1969-1974 Mauna Ulu eruption. Bull. Volcanol. 74(7), 1729-1743.

Pasqualon, N. G., 2017. Estratigrafia, petrologia e padrões de porosidade dos depósitos do Vulcão do Paredão, Ilha da Trindade, Brasil. Monography, Porto Alegre, Instituto de Geologia/Universidade Federal do Rio Grande do Sul, 143p.

Patrício, R.L., 2012. Mapeamento da Ilha de Trindade, Atlântico Sul. Monografia, Universidade Estadual Paulista, Brasil, 59p. (in Portuguese, with English Abstr.).

Pauling, B.D., Schiffman, P., Zierenberg, R.A., Clague, D.A., 2011. Environmental and chemical controls on palagonitization. Geochem. Geophys. Geosyst. 12 (12), 126.

Peacock, M.A., 1926a. The palagonite formation of Iceland. Geol. Mag. 63, 385-399. Peacock, M.A., 1926b. The geology of Videy, southwest Iceland; a record of igneous action in Glacial times. Trans. R. Soc. Edinburgh 5A, 441-465.

Peacock, M.A., 1926c. The petrology of Iceland, part I. The basic turfs. Trans. Roy. Soc. Edinburgh 55, 51-76.

Peacock, M.A., Fuller, R.E., 1928. Chlorophaeite, sideromelane, and palagonite from the Columbia River Plateau. Am. Mineral. 13, 360-382.

Pires, G.L.C., Bongiolo, E.M., Geraldes, M.C., Renac, C., Santos, A.C., Jourdan, F., Neumann, R., 2016. New ${ }^{40} \mathrm{Ar} /{ }^{39} \mathrm{Ar}$ ages and revised ${ }^{40} \mathrm{~K} /{ }^{40} \mathrm{Ar} *$ data from nephelinitic-phonolitic volcanic successions of the Trindade Island (South Atlantic Ocean). J. Volcanol. Geotherm. Res. 327, 531-538. 
Rader, E., Geist, D., 2015. Eruption conditions of spatter deposits. J. Volcanol. Geotherm. Res. 304, 287-293.

Searle, E.J., 1965. Auckland volcanic district in New Zealand volcanology.

Northland, Coromandel, Auckland. New Zeal. Geol. Surv. Handb., Info. Ser. 49, 90103.

Staudigel, H., Hart, S.R.,1983. Alteration of basaltic glass: mechanisms and significance for the oceanic crust-sea water budget. Geochim. Cosmochim. Acta 47, $337-350$.

Stearns, H.T., Vaksvik, K.N., 1935. Geology and ground-water resources of the island of Oahu, Hawaii. Hawaii Division of Hydrography Bulletin 1, U. S. Geological Survey, Hawaii, 479 p.

Stroncik, N.A., Schimincke, H.U., 2001. The evolution of palagonite: crystallization, chemical changes, and element budget. Geochem. Geophys. Geosyst. 2, 2000GC000102.

Stroncik, N.A., Schimincke, H.U., 2002. Palagonite- a review. Int. J. Earth Sci. 91, 680-697.

Sumner, J.M., Blake, S., Matela, R.J., Wolff, J.A., 2005. Spatter. J. Volcanol. Geotherm. Res. 142(1-2), 49-65.

Thorseth, I.H., Furnes, H., Tumyr, O., 1991. A textural and chemical study of Icelandic palagonite of varied composition and its bearing on the mechanism of the glass-palagonite transformation. Geochim. Cosmochim. Acta 55, 731-749.

Vergniolle, S., Brandeis, G., 1996. Strombolian explosions: 1. A large bubble breaking at the surface of a lava column as a source of sound. J. Geophys. Res. Solid Earth 101 (B9), 20433-20447.

Vergniolle, S., Brandeis, G., Mareschal, J.C., 1996. Strombolian explosions: 2. Eruption dynamics determined from acoustic measurements. J. Geophys. Res. Solid Earth 101 (B9), 20449-20466.

Walker, G.P.L, Croasdale, R., 1971. Characteristics of some basaltic pyroclastics. Bull. Volcanol. 35(2), 303-317. 
491 Wentworth, C.K., 1926. Pyroclastic geology of Oahu. Bernice P. Bishop. Museum,

492 Bulletin 30, Honolulu, Hawaii, 121 p. 
1: EDX analyses of sideromelane and palagonitized regions.

\begin{tabular}{|c|c|c|c|c|c|c|c|c|c|c|c|c|c|c|c|c|c|c|c|}
\hline & \multicolumn{4}{|c|}{$\begin{array}{c}\text { 1-palagonite } \\
\text { Figure 4A }\end{array}$} & \multicolumn{5}{|c|}{$\begin{array}{c}\text { 2-sideromelane } \\
\text { Figure 4C }\end{array}$} & \multicolumn{4}{|c|}{$\begin{array}{l}\text { 2-palagonite } \\
\text { Figure 4D, F }\end{array}$} & \multicolumn{3}{|c|}{$\begin{array}{c}\text { 3-sideromelane } \\
\text { Figure 4B }\end{array}$} & \multicolumn{3}{|c|}{$\begin{array}{c}\text { 3-palagonite } \\
\text { Figure 4B }\end{array}$} \\
\hline $\mathbf{N}^{\circ}$ & 1 & 2 & 3 & 4 & 1 & 2 & 3 & 4 & 5 & 1 & 2 & 3 & 4 & 1 & 2 & 3 & 4 & 5 & 6 \\
\hline \multicolumn{20}{|c|}{$\%$} \\
\hline $\mathrm{Na}_{2} \mathbf{O}$ & 0.30 & 0.22 & 0.23 & 0.49 & 5.72 & 5.51 & 5.44 & 6.11 & 6.21 & 0.23 & 0.45 & 1.12 & 0.42 & 3.56 & 3.65 & 3.68 & 0.15 & 0.04 & 0.07 \\
\hline $\mathrm{SiO}_{2}$ & 25.52 & 29.82 & 28.37 & 32.36 & 54.62 & 53.92 & 50.35 & 54.87 & 55.64 & 16.74 & 30.84 & 34.66 & 30.61 & 40.37 & 39.88 & 39.91 & 31.85 & 41.83 & 40.22 \\
\hline $\mathbf{A l}_{2} \mathbf{O}_{3}$ & 14.76 & 17.79 & 14.05 & 15.67 & 25.01 & 23.70 & 23.28 & 24.62 & 24.87 & 16.24 & 15.05 & 20.60 & 21.95 & 13.18 & 13.05 & 13.03 & 23.33 & 8.71 & 7.64 \\
\hline MgO & 1.34 & 1.86 & 1.65 & 3.05 & 0.11 & 0.69 & 0.66 & 0.14 & 0.17 & 0.41 & 2.24 & 1.27 & 0.74 & 5.04 & 4.99 & 5.02 & 0.72 & 0.86 & 0.73 \\
\hline $\mathrm{ZnO}$ & 0.00 & 0.02 & 0.00 & 0.19 & 0.07 & 0.04 & 0.00 & 0.04 & 0.02 & 0.00 & 0.00 & 0.00 & 0.00 & 0.09 & 0.01 & 0.00 & 0.03 & 0.07 & 0.00 \\
\hline $\mathrm{FeO}$ & 7.41 & 8.23 & 8.60 & 9.58 & 0.93 & 1.26 & 1.24 & 0.74 & 0.82 & 0.33 & 4.59 & 3.18 & 1.06 & 11.47 & 11.48 & 11.43 & 4.34 & 14.93 & 14.10 \\
\hline SrO & 0.00 & 0.00 & 0.00 & 0.00 & 0.01 & 0.04 & 0.05 & 0.04 & 0.01 & 0.02 & 0.16 & 2.60 & 0.30 & 0.00 & 0.00 & 0.00 & 0.00 & 0.00 & 0.00 \\
\hline $\mathrm{CaO}$ & 2.21 & 2.18 & 2.94 & 8.20 & 1.63 & 4.18 & 4.44 & 2.11 & 1.07 & 1.74 & 4.26 & 5.27 & 5.58 & 14.72 & 14.51 & 14.49 & 1.53 & 4.37 & 4.43 \\
\hline $\mathrm{Cr}_{2} \mathrm{O}_{3}$ & 0.00 & 0.00 & 0.00 & 0.30 & 0.00 & 0.09 & 0.14 & 0.00 & 0.06 & 0.11 & 0.00 & 0.00 & 0.08 & 0.00 & 0.04 & 0.05 & 0.03 & 0.00 & 0.04 \\
\hline $\mathbf{P}_{2} \mathbf{O}_{5}$ & 0.54 & 0.47 & 0.20 & 2.30 & 0.38 & 0.87 & 0.19 & 0.83 & 0.09 & 0.48 & 0.83 & 1.16 & 1.90 & 0.80 & 0.88 & 0.83 & 0.33 & 1.11 & 1.24 \\
\hline $\mathrm{NiO}$ & 0.05 & 0.02 & 0.00 & 0.01 & 0.00 & 0.02 & 0.00 & 0.00 & 0.02 & 0.00 & 0.01 & 0.03 & 0.02 & 0.00 & 0.00 & 0.00 & 0.04 & 0.00 & 0.03 \\
\hline $\mathbf{K}_{2} \mathbf{O}$ & 0.12 & 0.15 & 0.18 & 0.09 & 0.23 & 0.13 & 0.24 & 0.15 & 0.16 & 0.34 & 0.57 & 3.60 & 1.06 & 3.80 & 3.91 & 3.85 & 0.48 & 0.58 & 0.65 \\
\hline MnO & 0.07 & 0.06 & 0.08 & 0.09 & 0.03 & 0.00 & 0.06 & 0.00 & 0.02 & 0.00 & 0.07 & 0.18 & 0.00 & 0.19 & 0.15 & 0.17 & 0.00 & 0.00 & 0.00 \\
\hline $\mathrm{SO}_{3}$ & 0.04 & 0.06 & 0.02 & 0.13 & 0.02 & 0.06 & 0.07 & 0.01 & 0.02 & 0.47 & 0.02 & 0.04 & 0.07 & 0.19 & 0.18 & 0.16 & 0.13 & 0.01 & 0.00 \\
\hline $\mathrm{TiO}_{2}$ & 2.51 & 2.66 & 3.97 & 4.79 & 0.36 & 0.42 & 0.53 & 0.39 & 0.49 & 0.17 & 3.48 & 0.29 & 0.28 & 5.84 & 5.82 & 5.80 & 0.28 & 8.17 & 8.15 \\
\hline Total & 54.86 & 63.53 & 60.28 & 77.24 & 89.11 & 90.91 & 86.68 & 90.06 & 89.68 & 37.28 & 62.56 & 74.00 & 64.06 & 99.24 & 98.55 & 98.41 & 63.25 & 80.68 & 77.29 \\
\hline
\end{tabular}


497 Table 2: Micropobre analyses with ions calculated for clinopyroxene.

\begin{tabular}{|c|c|c|c|c|c|c|}
\hline & 1-Diopsidie & \multicolumn{4}{|c|}{ 2-Diopsidie } & 498 \\
\hline Region & Core & Edge & Interm. & Edge & Edge & A9ge \\
\hline \multicolumn{6}{|c|}{$\%$} & \\
\hline $\mathrm{SiO}_{2}$ & 41.33 & 42.79 & 47.36 & 47.41 & 47.30 & 46.41 \\
\hline $\mathrm{TiO}_{2}$ & 6.54 & 5.61 & 2.95 & 3.17 & 3.48 & 3.94 \\
\hline $\mathrm{Al}_{2} \mathrm{O}_{3}$ & 9.39 & 8.58 & 4.37 & 5.27 & 5.33 & 5042 \\
\hline $\mathrm{FeO}$ & 7.70 & 7.61 & 7.50 & 6.43 & 6.74 & 7.43 \\
\hline MgO & 10.93 & 11.72 & 16.87 & 13.67 & 13.42 & 159.98 \\
\hline MnO & 0.06 & 0.05 & 0.14 & 0.12 & 0.12 & 304 \\
\hline $\mathrm{CaO}$ & 23.56 & 23.87 & 21.62 & 23.30 & 23.73 & 23.76 \\
\hline $\mathrm{Na}_{2} \mathrm{O}$ & 0.43 & 0.46 & 0.29 & 0.29 & 0.32 & 0.35 \\
\hline $\mathrm{Cr}_{2} \mathrm{O}_{3}$ & 0.00 & 0.00 & 0.00 & 0.00 & 0.00 & 0.00 \\
\hline $\mathrm{NiO}$ & 0.00 & 0.00 & 0.00 & 0.00 & 0.00 & 0.00 \\
\hline $\mathbf{K}_{2} \mathbf{O}$ & 0.03 & 0.02 & 0.02 & 0.05 & 0.03 & 0.02 \\
\hline Total & 100.01 & 100.71 & 101.12 & 99.69 & 100.47 & 100.58 \\
\hline \multicolumn{7}{|c|}{ Calculation based on 6 oxygens } \\
\hline $\mathbf{S i}$ & 1.57 & 1.61 & 1.76 & 1.78 & 1.77 & 1.74 \\
\hline Ti & 0.19 & 0.16 & 0.08 & 0.09 & 0.10 & 0.11 \\
\hline Al & 0.42 & 0.38 & 0.19 & 0.23 & 0.23 & 0.24 \\
\hline $\mathbf{F e}$ & 0.25 & 0.24 & 0.23 & 0.20 & 0.21 & 0.23 \\
\hline Mg & 0.62 & 0.66 & 0.93 & 0,76 & 0.75 & 0.73 \\
\hline Mn & 0.00 & 0.00 & 0.00 & 0.00 & 0.00 & 0.00 \\
\hline $\mathbf{C a}$ & 0.96 & 0.96 & 0.86 & 0.94 & 0.95 & 0.95 \\
\hline $\mathbf{N a}$ & 0.03 & 0.03 & 0.02 & 0.02 & 0.02 & 0.03 \\
\hline $\mathrm{Cr}$ & 0.00 & 0.00 & 0.00 & 0.00 & 0.00 & 0.00 \\
\hline $\mathbf{N i}$ & 0.00 & 0.00 & 0.00 & 0.00 & 0.00 & 0.00 \\
\hline $\mathbf{K}$ & 0.00 & 0.00 & 0.00 & 0.00 & 0.00 & 0.00 \\
\hline Ens & 0.34 & 0.35 & 0.46 & 0.4 & 0.39 & 0.38 \\
\hline Fs & 0.13 & 0.13 & 0.12 & 0.11 & 0.11 & 0.12 \\
\hline Wo & 0.53 & 0.52 & 0.42 & 0.49 & 0.50 & 0.50 \\
\hline
\end{tabular}


Table 3: Chemical analysis by microprobe of the spinels of the pyroclasts 1,2 and 3 .

\begin{tabular}{|c|c|c|c|c|c|c|c|c|c|c|c|}
\hline & \multicolumn{4}{|c|}{1} & \multicolumn{4}{|c|}{2} & \multicolumn{3}{|c|}{3} \\
\hline & \multicolumn{4}{|c|}{ Fig. 4E } & \multicolumn{4}{|c|}{ Fig.4G } & \multicolumn{3}{|c|}{ Fig. 4H } \\
\hline $\begin{array}{c}\text { Region } \\
\text { No. } \\
\end{array}$ & $\begin{array}{c}\text { Edge } \\
1 \\
\end{array}$ & $\begin{array}{c}\text { Core } \\
2 \\
\end{array}$ & $\begin{array}{c}\text { Edge } \\
\mathbf{3} \\
\end{array}$ & $\begin{array}{c}\text { Core } \\
4 \\
\end{array}$ & $\begin{array}{c}\text { Edge } \\
1 \\
\end{array}$ & $\begin{array}{c}\text { Edge } \\
2 \\
\end{array}$ & $\begin{array}{c}\text { Core } \\
\mathbf{3} \\
\end{array}$ & $\begin{array}{c}\text { Core } \\
4 \\
\end{array}$ & $\begin{array}{c}\text { Edge } \\
1 \\
\end{array}$ & $\begin{array}{c}\text { Core } \\
2 \\
\end{array}$ & $\begin{array}{c}\text { Edge } \\
\mathbf{3} \\
\end{array}$ \\
\hline \multicolumn{12}{|c|}{$\%$} \\
\hline $\mathrm{SiO}_{2}$ & 0.04 & 0.07 & 0.00 & 0.06 & 0.14 & 0.04 & 0.03 & 0.09 & 0.05 & 0.00 & 0.03 \\
\hline $\mathrm{Al}_{2} \mathrm{O}_{3}$ & 4.96 & 6.12 & 5.44 & 5.74 & 2.14 & 8.29 & 18.07 & 7.25 & 5.18 & 21.755 & 5.29 \\
\hline MgO & 5.63 & 9.52 & 8.09 & 7.26 & 1,267 & 3.83 & 11.67 & 4.40 & 8.01 & 10.789 & 8.15 \\
\hline $\mathrm{FeO}$ & 56.60 & 50.10 & 53.13 & 54.64 & 71.99 & 61.453 & 33.44 & 62.03 & 60.61 & 37.396 & 59.67 \\
\hline $\mathrm{Cr}_{2} \mathrm{O}_{3}$ & 0.88 & 6.88 & 6.28 & 2.48 & 3.19 & 5.47 & 2.96 & 8.69 & 1.97 & 20.434 & 3.10 \\
\hline MnO & 0.36 & 0.42 & 0.47 & 0.77 & 0.18 & 0.29 & 4.07 & 0.44 & 0.39 & 0.13 & 0.45 \\
\hline $\mathrm{TiO}_{2}$ & 21.77 & 16.70 & 17.74 & 20.18 & 10.392 & 9.12 & 2.30 & 5.34 & 18.94 & 4.65 & 17.93 \\
\hline Total & 90.30 & 89.80 & 91.15 & 91.13 & 89.307 & 88.501 & 93.55 & 88.24 & 95.75 & 9549 & 95.05 \\
\hline
\end{tabular}

Calculation based on 4 oxygens

\begin{tabular}{l|llll|llll|lll}
\hline $\mathbf{S i}$ & 0.001 & 0.002 & 0.002 & 0.002 & 0.002 & 0.002 & 0.002 & 0.002 & 0.002 & 0.002 & 0.002 \\
$\mathbf{T i}$ & 0.622 & 0.561 & 0.561 & 0.561 & 0.561 & 0.561 & 0.561 & 0.561 & 0.561 & 0.561 & 0.561 \\
$\mathbf{A l}$ & 0.222 & 0.250 & 0.250 & 0.250 & 0.250 & 0.250 & 0.250 & 0.250 & 0.250 & 0.250 & 0.250 \\
$\mathbf{C r}$ & 0.027 & 0.073 & 0.073 & 0.073 & 0.073 & 0.073 & 0.073 & 0.073 & 0.073 & 0.073 & 0.073 \\
$\mathbf{F e}^{+\mathbf{2}}$ & 0.506 & 0.550 & 0.550 & 0.550 & 0.550 & 0.550 & 0.550 & 0.550 & 0.550 & 0.550 & 0.550 \\
$\mathbf{F e}^{+3}$ & 1.293 & 1.139 & 1.139 & 1.139 & 1.139 & 1.139 & 1.139 & 1.139 & 1.139 & 1.139 & 1.139 \\
$\mathbf{M n}$ & 0.012 & 0.024 & 0.024 & 0.024 & 0.024 & 0.024 & 0.024 & 0.024 & 0.024 & 0.024 & 0.024 \\
$\mathbf{M g}$ & 0.319 & 0.400 & 0.400 & 0.400 & 0.400 & 0.400 & 0.400 & 0.400 & 0.400 & 0.400 & 0.400 \\
\hline
\end{tabular}


525 Table 4: Chemical analysis by microprobe of the zeolites of the pyroclast 2.

\begin{tabular}{|c|c|c|c|c|}
\hline Mineral & Heulandite-Ca & Chabazite-Ca & Chabazite-Ca & Chabazite-Ca \\
\hline Region & $\begin{array}{l}\text { Amygdale filled } \\
\text { Fig. } 4 \mathrm{G}\end{array}$ & $\begin{array}{l}\text { Fracture } \\
\text { Fig. } 4 \mathrm{G}\end{array}$ & $\begin{array}{c}\text { Fracture } \\
\text { Fig. 4F }\end{array}$ & $\begin{array}{c}\text { Amygdale } \\
\text { partially filled } \\
\text { Fig. } 4 \mathrm{G}\end{array}$ \\
\hline $\mathbf{N}^{\circ}$ & 5 & 6 & 5 & 7 \\
\hline \multicolumn{5}{|c|}{$\%$} \\
\hline $\mathrm{SiO}_{2}$ & 48.21 & 47.09 & 45.87 & 49.18 \\
\hline $\mathrm{TiO}_{2}$ & 0.09 & 0.05 & 0.00 & 0.00 \\
\hline $\mathrm{Al}_{2} \mathrm{O}_{3}$ & 19.60 & 23.25 & 24.02 & 23.92 \\
\hline $\mathrm{FeO}$ & 1.06 & 0.18 & 0.24 & 0.32 \\
\hline MgO & 0.13 & 0.20 & 0.05 & 0.30 \\
\hline MnO & 0.05 & 0.00 & 0.00 & 0.00 \\
\hline $\mathrm{CaO}$ & 6.60 & 7.57 & 8.74 & 7.52 \\
\hline $\mathrm{Na}_{2} \mathrm{O}$ & 0.49 & 0.13 & 0.36 & 0.31 \\
\hline $\mathbf{K}_{2} \mathbf{O}$ & 4.24 & 0.69 & 4.98 & 0.91 \\
\hline $\mathrm{Cr}_{2} \mathrm{O}_{3}$ & 0.03 & 0.04 & 0.00 & 0.00 \\
\hline $\mathrm{H}_{2} \mathrm{O}$ & 19.50 & 20.80 & 14.23 & 17.54 \\
\hline Total & 100.00 & 100.00 & 100.00 & 100.00 \\
\hline & $\begin{array}{c}\text { Calculation } \\
\text { based on } 98 \\
\text { oxygens }\end{array}$ & \multicolumn{3}{|c|}{ Calculation based on 36 oxygens } \\
\hline Si & 21.58 & 7.60 & 8.08 & 8.16 \\
\hline Ti & 0.00 & 0.00 & 0.00 & 0.00 \\
\hline Al & 10.34 & 4.42 & 4.99 & 4.68 \\
\hline $\mathbf{F e}$ & 0.40 & 0.02 & 0.04 & 0.04 \\
\hline Mg & 0.09 & 0.05 & 0.01 & 0.08 \\
\hline Mn & 0.02 & 0.00 & 0.00 & 0.00 \\
\hline $\mathbf{C a}$ & 3.17 & 1.31 & 1.65 & 1.34 \\
\hline $\mathbf{N a}$ & 0.85 & 0.08 & 0.25 & 0.20 \\
\hline $\mathbf{K}$ & 4.84 & 0.28 & 2.24 & 0.38 \\
\hline $\mathrm{Cr}$ & 0.00 & 0.00 & 0.00 & 0.00 \\
\hline $\mathbf{H}$ & 65.50 & 25.18 & 18.82 & 21.84 \\
\hline
\end{tabular}


Table 5: Chemical analyses of the major elements, trace and REE in representative samples of pyroclasts of the Vulcão do Paredão (1) and Morro Vermelho (2 and 3). LQ

$542=$ Quantification Limit.

\begin{tabular}{|c|c|c|c|c|c|c|c|c|c|c|c|c|c|c|}
\hline \multicolumn{15}{|c|}{ Pyroclasts } \\
\hline & \multicolumn{14}{|c|}{$\%$} \\
\hline & $\mathrm{SiO}_{2}$ & $\mathbf{A l}_{2} \mathbf{O}_{3}$ & $\mathrm{FeO}_{\mathrm{t}}$ & $\mathrm{TiO}_{2}$ & $\mathrm{CaO}$ & $\mathrm{Na}_{2} \mathrm{O}$ & $\mathbf{K}_{2} \mathbf{O}$ & MgO & MnO & $\mathbf{P}_{2} \mathbf{O}_{5}$ & LOI & $\mathrm{K}_{2} \mathrm{O} / \mathrm{Na}_{2} \mathrm{O}$ & Total & \\
\hline 1 & 37.47 & 14.68 & 19.58 & 6.95 & 5.43 & 0.53 & 0.15 & 4.50 & 0.30 & 1.36 & 9.05 & 0.28 & 100.00 & \\
\hline 2 & 37.50 & 11.95 & 16.09 & 5.36 & 11.15 & 0.57 & 0.27 & 7.37 & 0.27 & 1.48 & 7.99 & 0.47 & 100.00 & \\
\hline 3 & 37.81 & 13.38 & 18.46 & 7.31 & 3.50 & 0.29 & 0.48 & 3.67 & 0.30 & 0.86 & 13.95 & 1.65 & 100.00 & \\
\hline \multicolumn{15}{|c|}{ Ppm } \\
\hline & As & $\mathbf{B a}$ & Co & $\mathrm{Cr}$ & $\mathrm{Cu}$ & $\mathbf{L i}$ & Mo & $\mathrm{Ni}$ & $\mathrm{Sr}$ & Th & $\mathbf{V}$ & $\mathbf{Z n}$ & $\mathbf{B e}$ & Sb \\
\hline 1 & $<\mathrm{LQ}$ & 1377.45 & 127.12 & 252.82 & 44.73 & 14.35 & $<\mathrm{LQ}$ & 115.04 & 1240.76 & 33.40 & 248.97 & 145.55 & 1.08 & $<\mathrm{LQ}$ \\
\hline 2 & $<\mathrm{LQ}$ & 1608.22 & 92.73 & 363.23 & 75.9 & 10.94 & $<\mathrm{LQ}$ & 127.93 & 1592.12 & 39.5 & 302.20 & 128.11 & 1.00 & $<\mathrm{LQ}$ \\
\hline \multirow[t]{2}{*}{3} & $<\mathrm{LQ}$ & 1887.55 & 116.35 & 472.19 & 87.47 & 9.69 & $<\mathrm{LQ}$ & 115.02 & 566.09 & 32.02 & 275.81 & 172.75 & 1.13 & $<\mathrm{LQ}$ \\
\hline & $\mathrm{Zr}$ & $\mathbf{P b}$ & $\mathbf{S}$ & Sc & $\mathbf{G a}$ & $\mathbf{Y}$ & Cd & In & Cs & $\mathbf{L a}$ & $\mathrm{Ce}$ & Pr & Nd & Sm \\
\hline 1 & 314.24 & $<\mathrm{LQ}$ & 220.20 & 34.83 & 33.44 & 42.62 & 1.86 & 0.15 & 1.04 & 101.82 & 267.19 & 27.42 & 109.93 & 20.58 \\
\hline 2 & 279.70 & $<\mathrm{LQ}$ & 110.88 & 29.49 & 28.96 & 48.56 & 0.88 & 0.12 & 0.75 & 124.19 & 299.11 & 32.55 & 131.87 & 24.14 \\
\hline \multirow[t]{2}{*}{3} & 308.19 & $<\mathrm{LQ}$ & 65.44 & 37.16 & 33.80 & 41.28 & 0.50 & 0.16 & 0.62 & 89.93 & 229.24 & 23.99 & 97.44 & 18.72 \\
\hline & $\mathbf{E u}$ & Gd & $\mathbf{T b}$ & Dy & Ho & $\mathbf{E r}$ & $\mathbf{T m}$ & $\mathbf{Y b}$ & Lu & Tl & $\mathbf{P b}$ & $\mathbf{B i}$ & Th & $\mathbf{U}$ \\
\hline 1 & 6.34 & 18.01 & 2.00 & 10.1 & 1.67 & 4.03 & 0.46 & 2.56 & 0.35 & $<\mathrm{LQ}$ & 4.19 & $<\mathrm{LQ}$ & 8.86 & 2.51 \\
\hline 2 & 7.28 & 20.60 & 2.25 & 11.26 & 1.87 & 4.66 & 0.53 & 3.04 & 0.41 & $<\mathrm{LQ}$ & 10.64 & $<\mathrm{LQ}$ & 11.09 & 2.68 \\
\hline 3 & 5.85 & 16.37 & 1.87 & 9.67 & 1.64 & 4.04 & 0.48 & 2.68 & 0.36 & $<\mathrm{LQ}$ & 12.23 & 0,043 & 8.81 & 2.01 \\
\hline
\end{tabular}




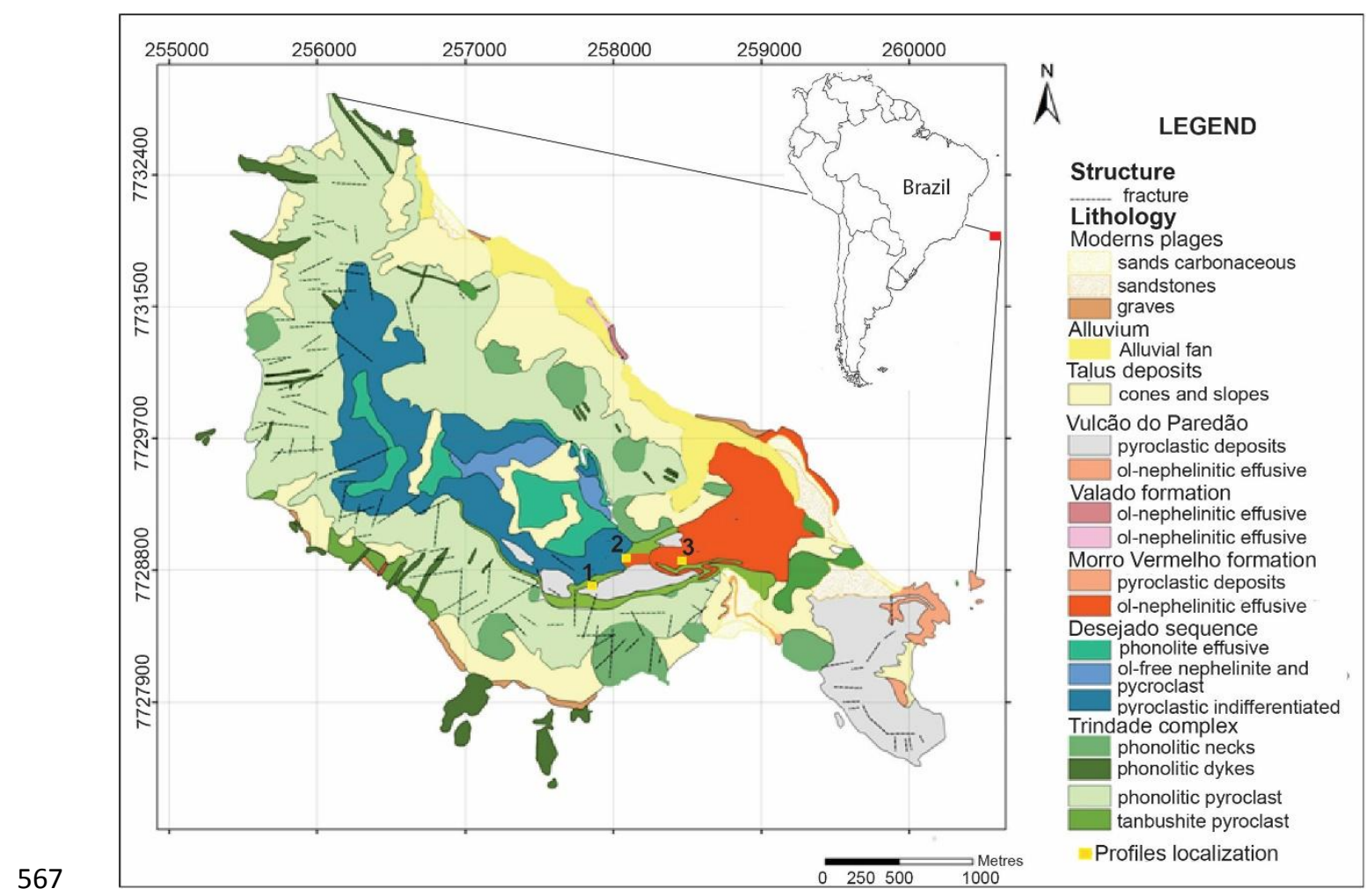

568 Figure 1: Geological map of Trindade Island and the regions of collection of pyroclasts 569 1, 2 and 3. Modified of Patrício (2012). 

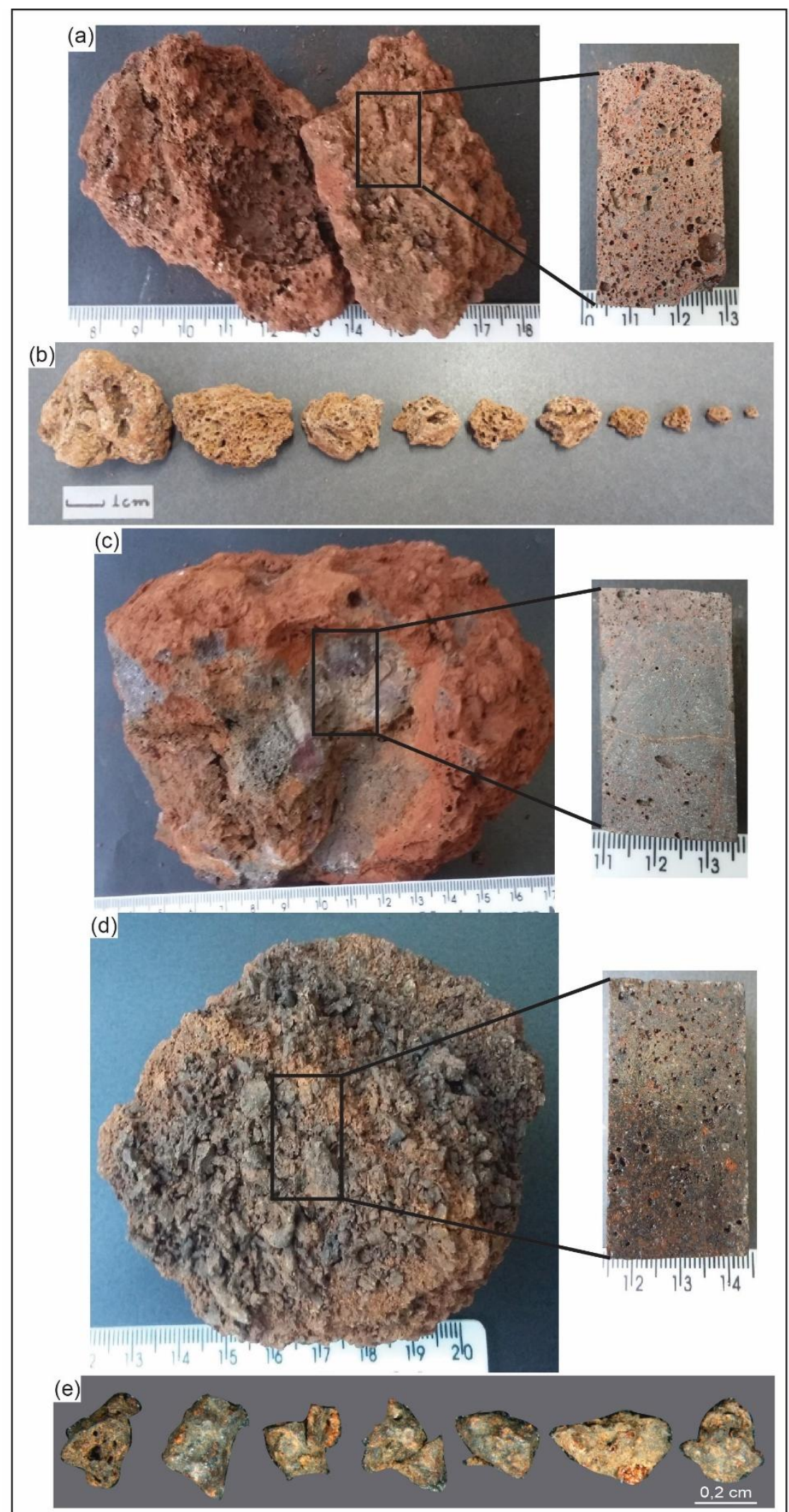

573 alteration features. On the right, sample where the blade was made for the

574 micromorphological description. (b) Image showing lapilli of different sizes in

575 pyroclast 1. (c) Pyroclast 2 of the Morro Vermelho formation, with the altered edges of 
reddish coloration. On the right, image of the sample where the blade was made for the micromorphological description. (d) Pyroclast 3 of the Morro Vermelho formation. On the right is the sample where the blade was made for micromorphological description. It is possible to observe reddish-colored alteration features. (e) Image showing smaller lapilli grains of $2 \mathrm{~mm}$ with alteration features.
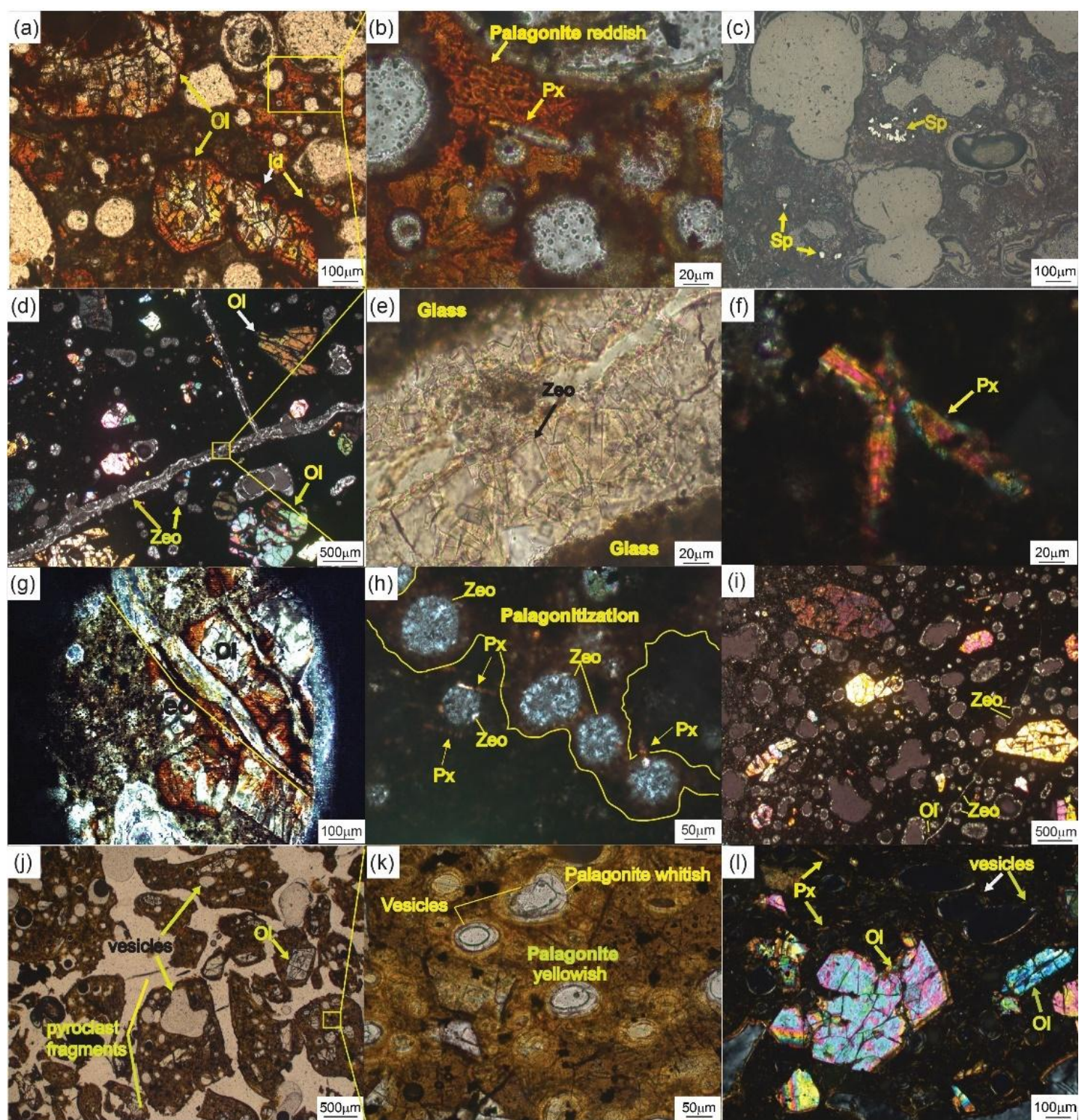

Figure 3: Pyroclast 1: (a) PPL photomicrograph from the euhedral olivine phenocrystals with altered borders for iddingsite wrapped by reddish brown matrix. (b) PPL photomicrograph from the prismatic pyroxene near vesicles wrapped in palagonite. (c) Reflected light photomicrograph showing the crystals of spinel in the matrix. 
587 Pyroclast 2: (d) XPL photomicrograph showing hypocrystalline structure, veins and 588 vesicles partially and totally filled by zeolites. (e) PPL photomicrograph from the 589 rhombohedral zeolites with low relief and glass volcanic grayish. (f) XPL 590 photomicrograph from the pyroxenes intercrossed. (g) PPL photomicrograph showing 591 vein of zeolite cutting olivine crystal. (h) PPL photomicrograph showing 592 hypocrystalline structure and partial vesicles and fully filled by zeolites. (i) XPL 593 photomicrograph from vein of zeolite cutting vesicles filled by zeolite.

594 Pyroclast 3: (j) XPL photomicrograph from the fragments of $2 \mathrm{~mm}$ pyroclasts with 595 vesicles structure. (k) PPL photomicrograph showing fully palagonitized glass and 596 region with white palagonite. (1) XPL photomicrograph from the hypocrystalline matrix 597 with vesicles and small crystals of pyroxenes around phenocrystals of fractured 598 olivines. Some olivine crystals are euhedral. XPL $=$ cross polarized light; PPL $=$ plane 599 polarized light; $\mathrm{Ol}=$ olivine; $\mathrm{Px}=$ pyroxene; $\mathrm{Sp}=$ spinel, $\mathrm{Zeo}=$ zeolite. 

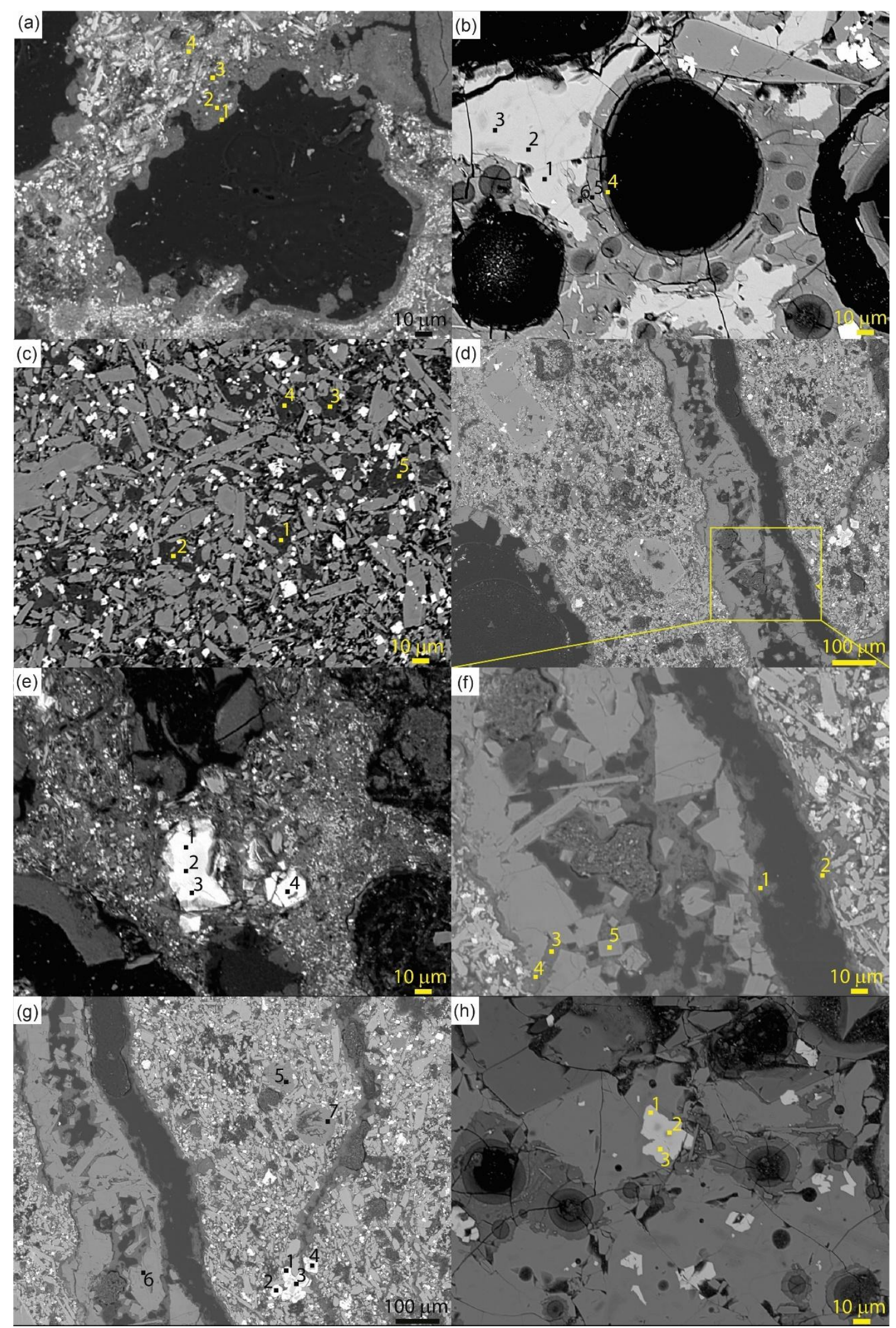

602 Figure 4: SEM photomicrograph and point of microchemical analyses by micropobre of pyroclasts. Pyroclast 1: (a) Punctual analysis of the palagonite in the wall and around a vesicle, (e) Punctual analysis of two spinel crystals. 
Pyroclast 2: (c) Punctual analyses in sideromelane in the microlytic matrix, (d) and (f) Punctual analyses in a fracture filled by zeolites and palagonite. (g) Analysis of amygdales filled by zeolites and analysis of spinels crystals.

Pyroclast 3: (b) Analysis of sideromelane and its alteration to palagonite., (h) Analyses of zoned spinel crystals.
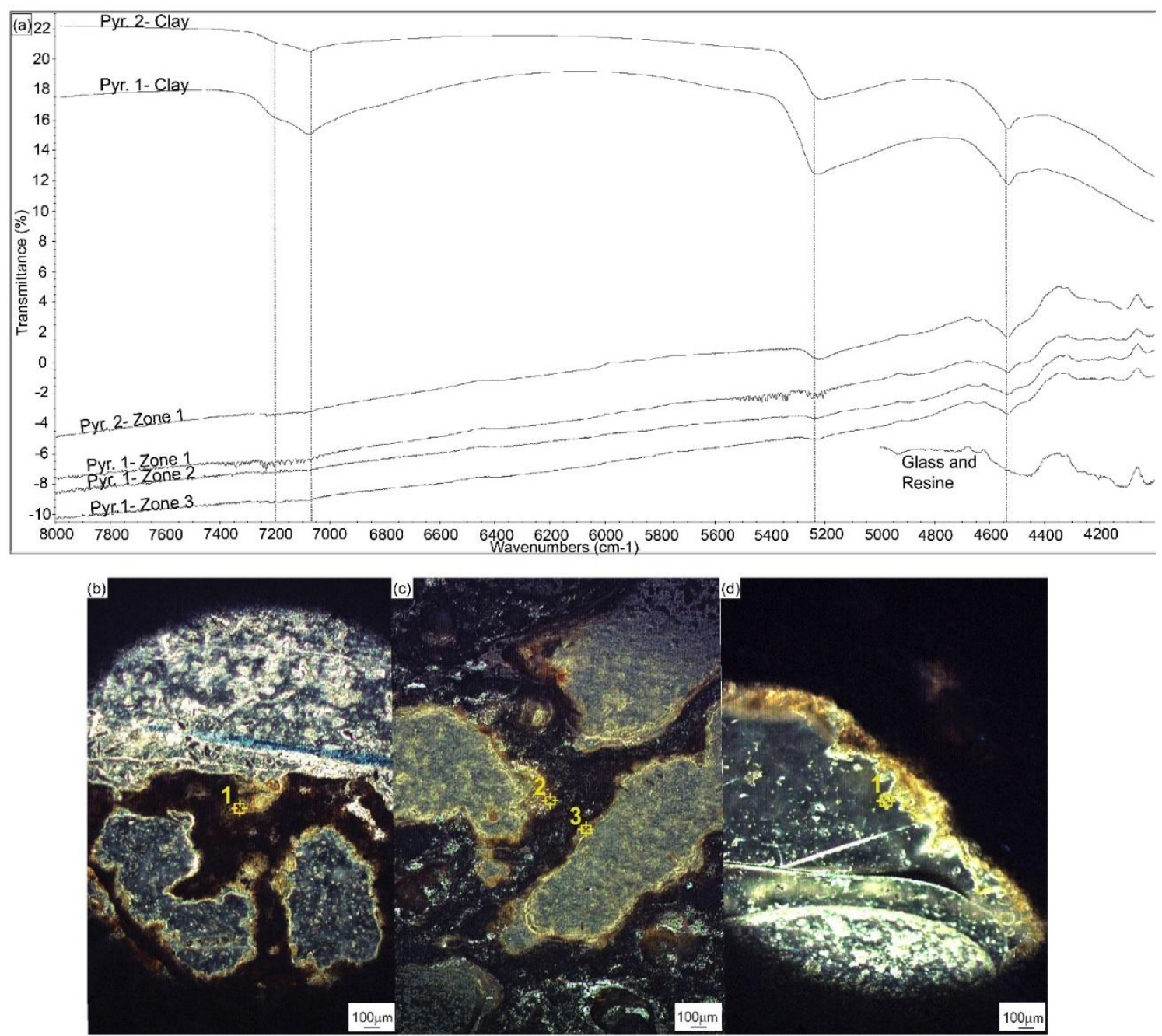

Figure 5: (a) NIR analysis of clay and palagonitized portions of pyroclast 1 and 2 showing the presence of halloysite. The clay analysis was used to compare the positions of the signals between 7000 and $7230 \mathrm{~cm}^{-1}$, since the signal in the palagonitized region is weak due to thickness and resin of the slender section. The spectrum of resine and glass was obtained to show the regions when occurs signal of resine and glass in spectrum of thin section. b, c and d) XPL photomicrograph in regions palagonitized and points of the analysis of the pyr. 1 (b and c) and pyr. 2 (d). Pyr=pyroclasts. 

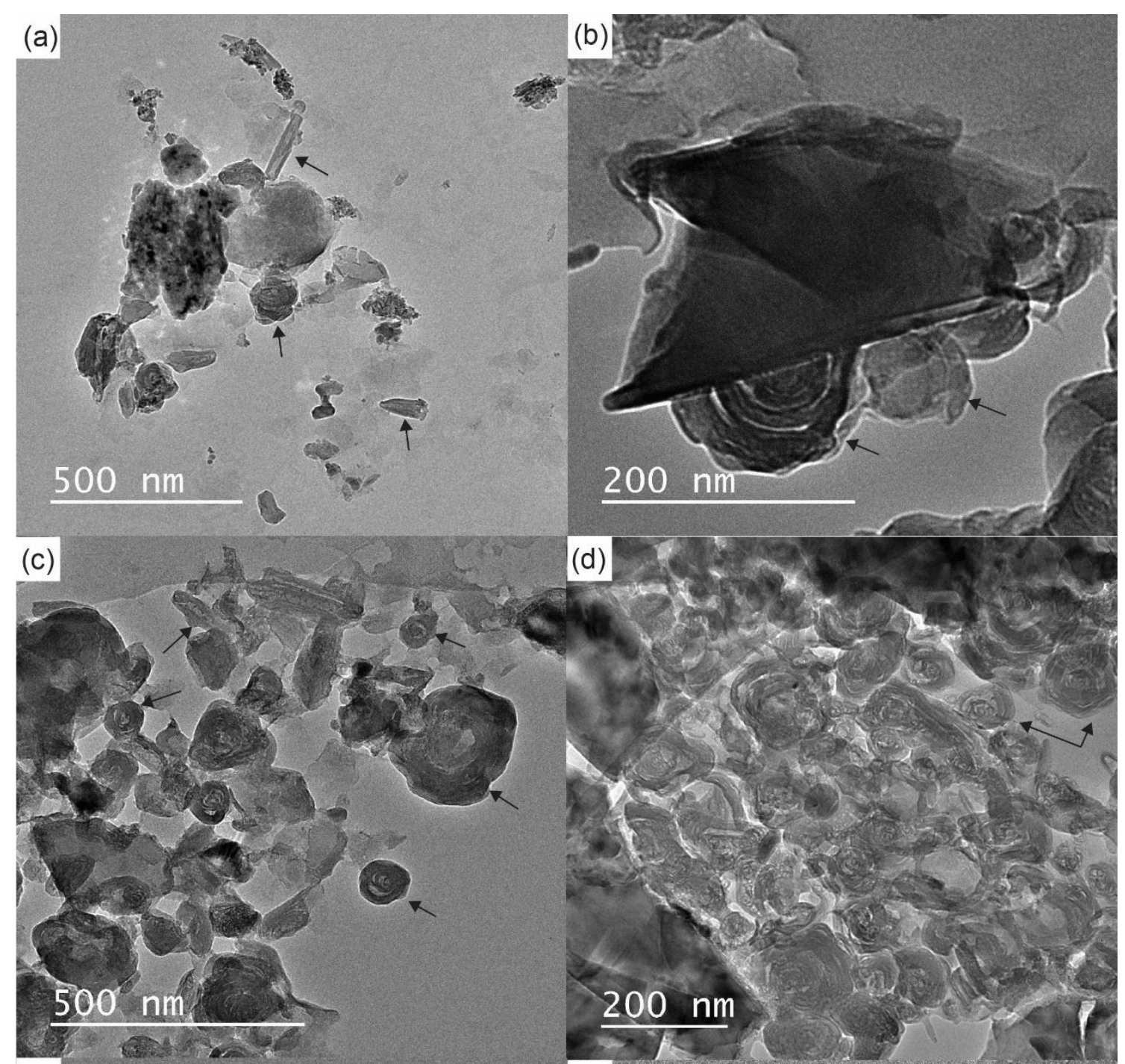

(e)
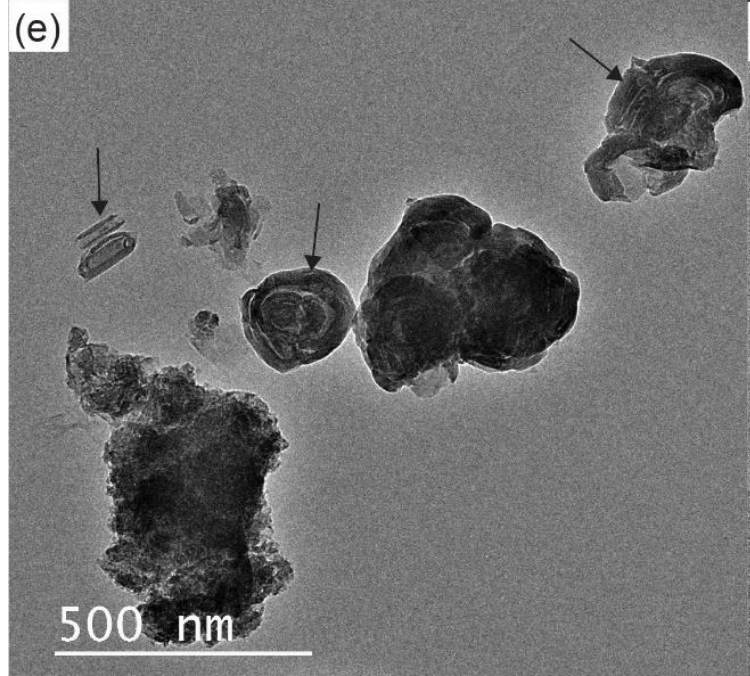

(d)

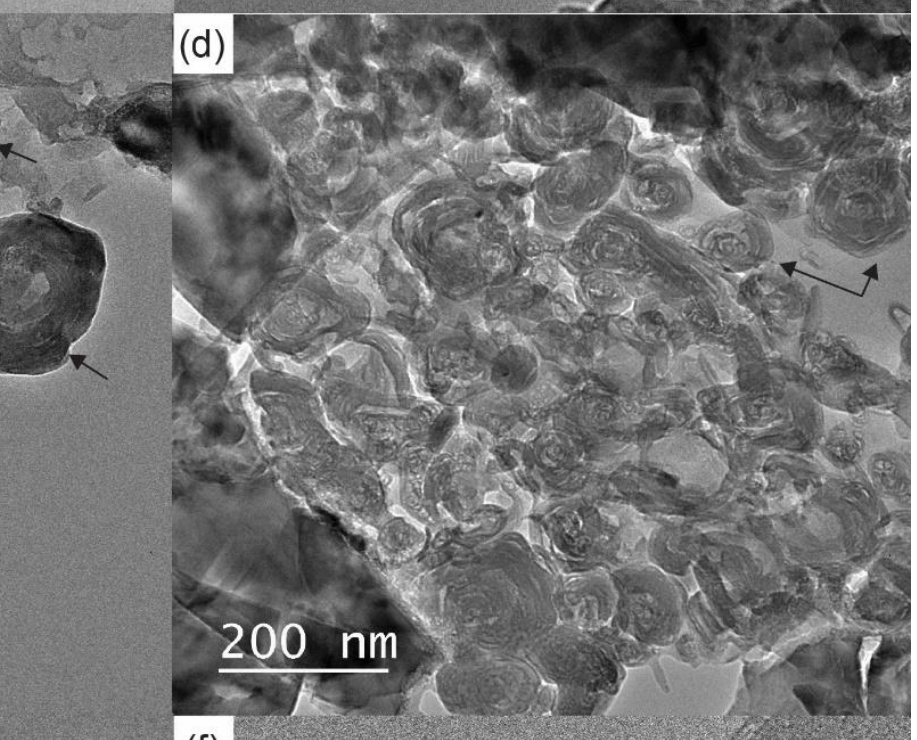

(f)

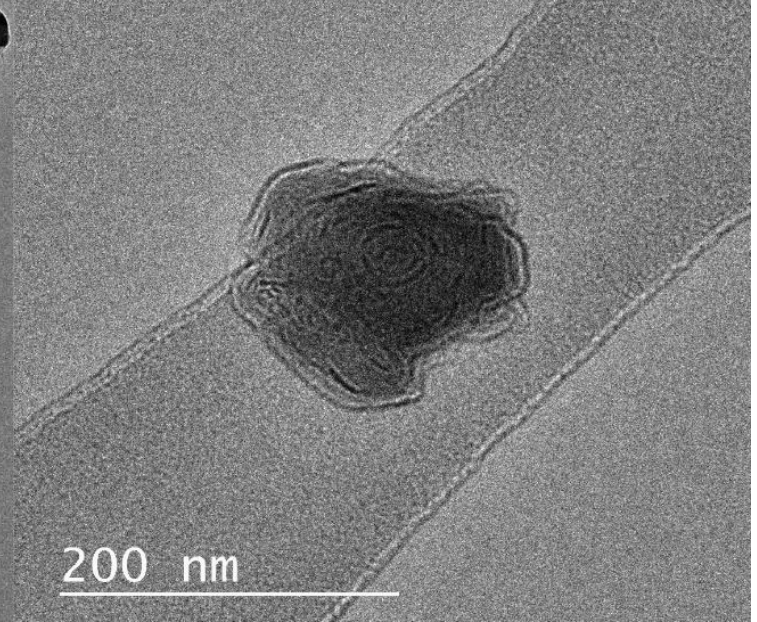

620 Figure 6: TEM images of halloysites in clay fraction of altered regions of the pyroclast

6211 (a), 2 (c), and 3 (e) and halloysites in regions with palagonitization (pyroclast 1-b, 2-d and 3-f). In all figures the arrows indicate the tubular halloysite crystals. The figure $b$ 
623 shows the fragment of volcanic glass on halloysite crystals. In the lower left corner of 624 figure d occurs a fragment of pyroxene.

625

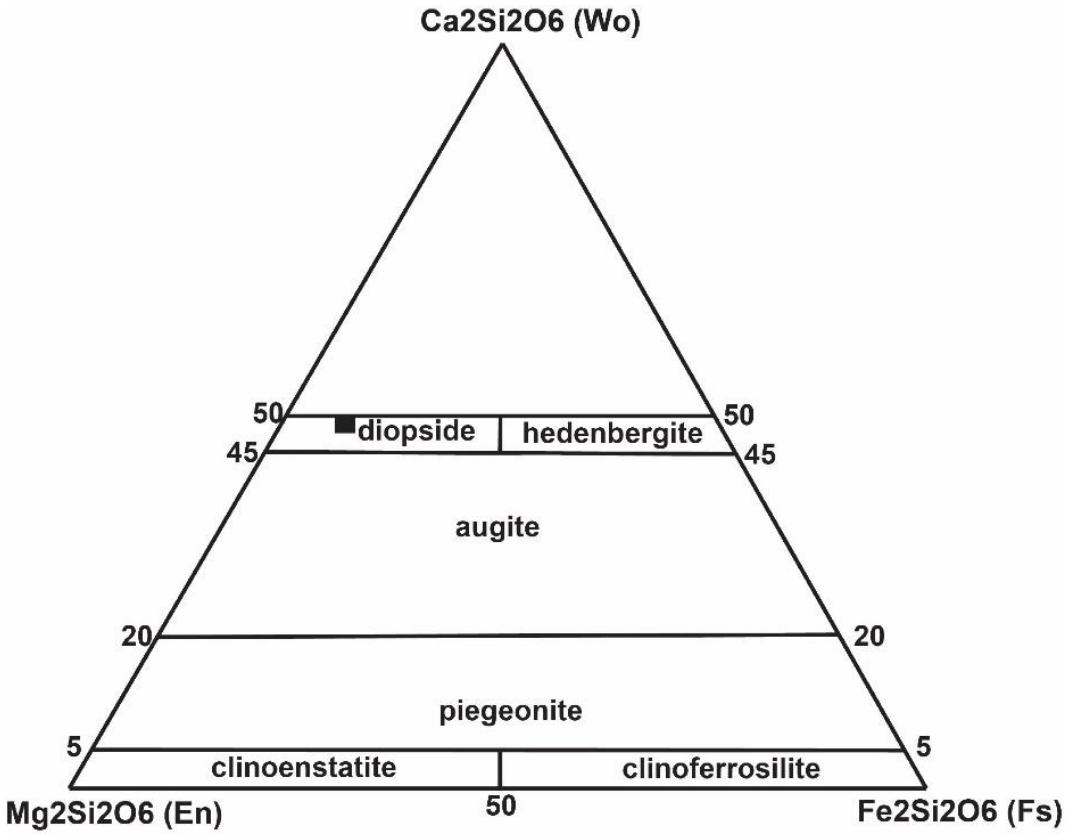

627 Figure 7: Morimoto diagram (1988) modified showing the composition of the 628 clinopyroxene. The square indicates the pyroclasts 1 and 2.

629

630

631 


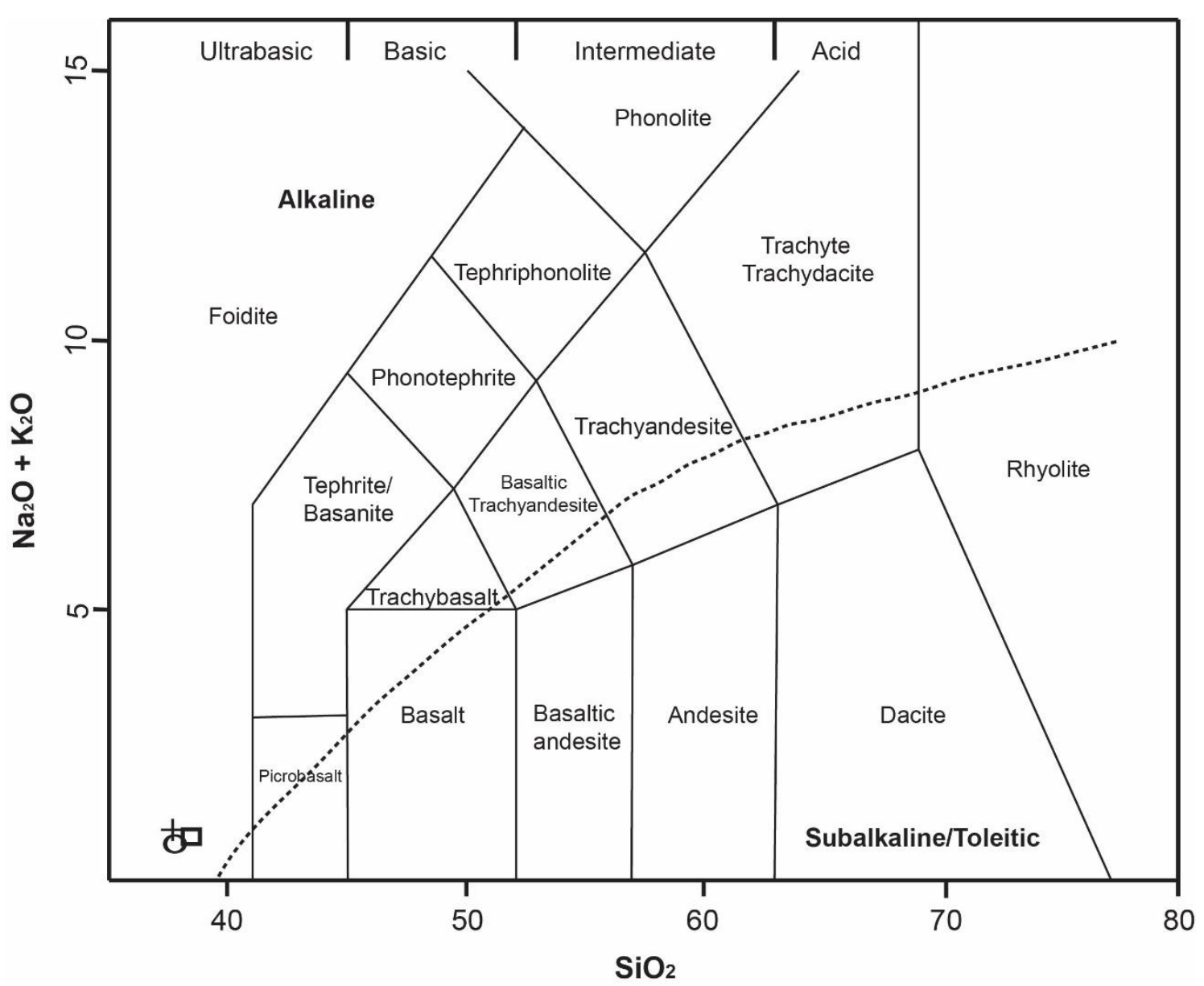

Figure 8: TAS diagram (Les Bas et al. 1986) for the pyroclasts 1 (circle) of the Vulcão do Paredão and, 2 (cross) and 3 (square), both of Morro Vermelho formation.

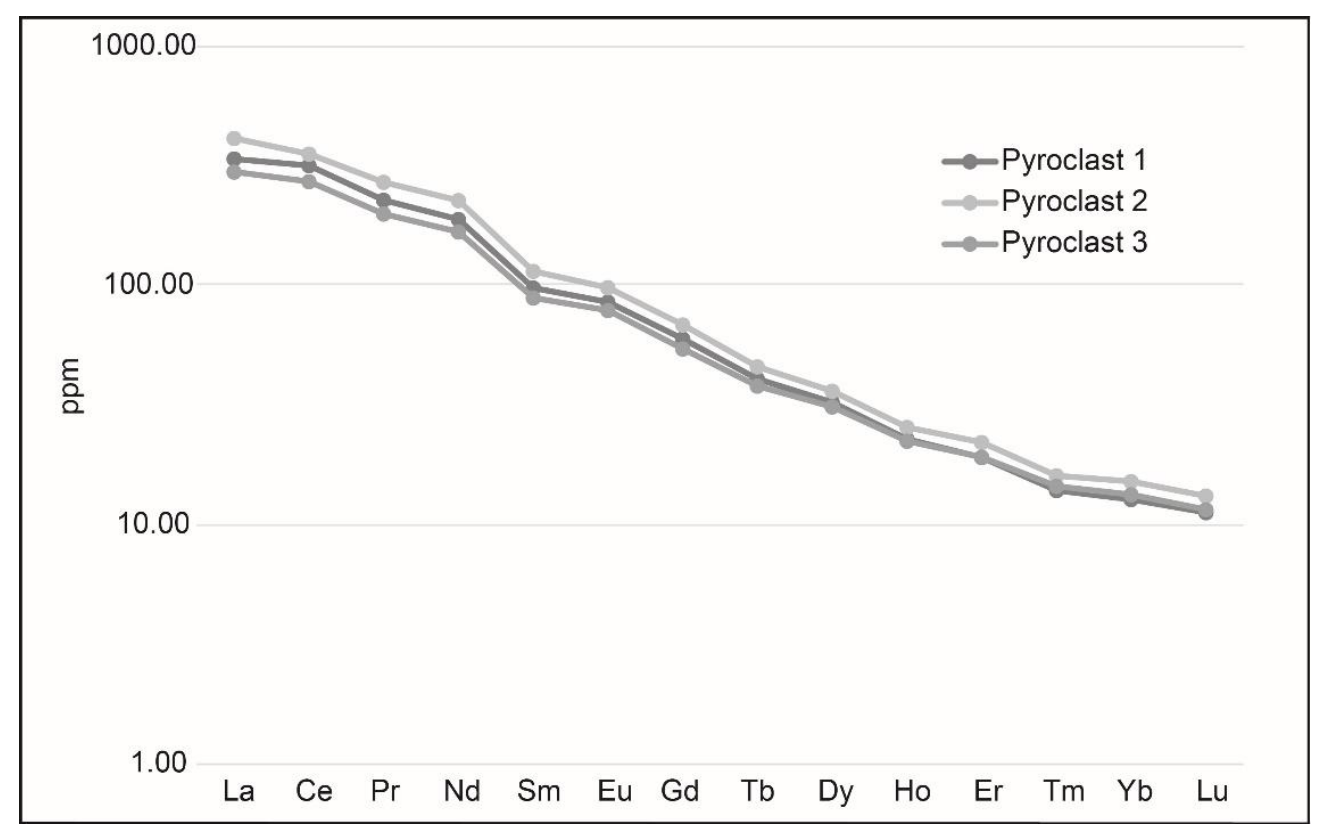

Figure 9: Typical chondrite-normalized (McDonough and Sun,1995) rare-earth-element (REE) plots of pyroclasts. 